\title{
Dissolved methane in the sills region of the Gulf of California
}

\section{Metano disuelto en la región de umbrales del golfo de California}

\author{
José Vinicio Macías-Zamora ${ }^{1 *}$, Karel Castro-Morales ${ }^{1,4}$, Roger Allen Burke ${ }^{2}$, \\ Manuel López-Mariscal ${ }^{3}$
}

${ }^{1}$ Instituto de Investigaciones Oceanológicas, Universidad Autónoma de Baja California, Carretera TijuanaEnsenada No. 3917, Fraccionamiento Playitas, Ensenada, CP 22860, Baja California, México.

${ }^{2}$ US Environmental Protection Agency, National Exposure Research Laboratory, 960 College Station Road, Athens, GA 30605, USA.

${ }^{3}$ Departamento de Oceanografía Física, Centro de Investigación Científica y de Educación Superior de Ensenada, Carretera Ensenada-Tijuana No. 3918, Fraccionamiento Playitas, Ensenada, CP 22860, Baja California, México.

${ }^{4}$ Alfred Wegener Institute Helmholtz Centre for Polar and Marine Research, Am Handelshafen 12, Bremerhaven, 27570, Germany.

*Corresponding author. E-mail: vmacias@uabc.edu.mx

\begin{abstract}
An unusual combination of features makes the Midriff Islands region of the northern Gulf of California (NGC) a strong atmospheric methane source. Oceanographic isolation by a series of sills and islands along with upward transport of nutrient-rich water enhanced by tidal currents, upwelling, and overflows results in high productivity. The resulting high phytoplankton biomass likely stimulates biogeochemical cycling that, in turn, may stimulate biological methane production in the water column and sediments. Additionally, venting of abiogenic methane-rich hydrothermal fluids in this tectonically active area and seepage of biogenic or thermogenic methane gas from the sediments may also be important sources. We found elevated methane concentrations throughout our study area, the highest within the Ballenas Channel, which was supersaturated with respect to atmospheric methane at all depths. Our vertical methane profiles show that elevated dissolved methane concentrations in the NGC are mainly associated with Gulf of California Water (GCW). Data from 22 stations suggest southward advection of methane via the methane-rich GCW, and lower methane concentrations south of the sills area. Our observations of supersaturated methane concentrations at all stations and all depths in the Ballenas Channel suggest that it is a strong source of methane to the atmosphere and to other parts of the NGC. In particular, station 7 at 50, 20, and $0 \mathrm{~m}$ depths had methane $\left(\mathrm{CH}_{4}\right)$ concentrations of $49.1,48.3$, and $43.5 \mathrm{nM}$, respectively, corresponding to saturation values of $2090 \%, 2050 \%$, and $1850 \%$, respectively. Our calculated NGC fluxes ranged from 3.4 to $103.4 \mu \mathrm{mol} \mathrm{CH}_{4} \mathrm{~m}^{-2} \mathrm{~d}^{-1}$. The average methane flux calculated for our entire study area was $21.1 \mu \mathrm{mol} \mathrm{CH}_{4} \mathrm{~m}^{-2} \mathrm{~d}^{-1}$. These values are higher than those measured at many other high productivity sites worldwide including upwelling sites, and suggest input of methane via hydrothermal fluids or seepage from the sediments.
\end{abstract}

Key words: dissolved methane, gas chromatography, potential methane sources and origin.

RESUMEN. Una combinación inusual de rasgos oceanográficos hacen de la región de las grandes islas del norte del golfo de California (NGC) una importante fuente de metano hacia la atmósfera. El aislamiento oceanográfico por umbrales e islas y el transporte vertical de agua rica en nutrientes, aumentado por mareas, surgencias y desbordes, resultan en alta productividad. La alta biomasa fitoplanctónica probablemente estimula el reciclado biogeoquímico, que a su vez estimula la producción biológica de metano en el agua y sedimento. Adicionalmente, el venteo de fluidos hidrotermales ricos en metano en esta zona tectónicamente activa y las filtraciones de gas metano, termogénico o biogénico, del sedimento también pueden ser fuentes importantes. Se encontraron concentraciones elevadas de metano a lo largo del área de estudio, principalmente dentro del canal de Ballenas, con supersaturación respecto al metano atmosférico en todas las profundidades. Nuestros perfiles verticales de metano muestran que las elevadas concentraciones de metano en el NGC están asociadas al Agua del Golfo de California (AGC). Datos de 22 estaciones sugieren una advección de metano al sur vía AGC rica en metano, y concentraciones menores de metano al sur de los umbrales. La supersaturación en el canal de Ballenas sugiere que éste es una fuente importante de metano hacia la atmósfera y hacia otras partes del NGC. En particular, la estación 7 a 50, 20 y $0 \mathrm{~m}$ de profundidad presentó concentraciones de metano $\left(\mathrm{CH}_{4}\right)$ de $49.1,48.3$ y $43.5 \mathrm{nM}$, respectivamente (saturaciones de 2090\%, 2050\% y 1850\%, respectivamente). El flujo de gas hacia la atmósfera varió de 3.4 a $103.4 \mu \mathrm{mol}_{\mathrm{CH}_{4}}$ $\mathrm{m}^{-2} \mathrm{~d}^{-1}$, con un promedio total para toda el área de $21.1 \mu \mathrm{mol} \mathrm{CH}_{4} \mathrm{~m}^{-2} \mathrm{~d}^{-1}$. Estos valores son más altos comparados con aquellos medidos en otros sitios de alta productividad a nivel mundial, incluyendo zonas de surgencias, y sugieren una entrada de metano vía procesos hidrotermales o filtraciones desde el sedimento.

Palabras clave: metano disuelto, cromatografía de gases, origen y fuentes potenciales de metano. 


\section{INTRODUCTION}

Methane is an important greenhouse gas that contributes about 15\% (Amouroux et al. 2002) to 21\% (Houghton et al. 1990) of the total radiative forcing from long-lived greenhouse gases. Although the atmospheric methane concentration has been generally rising since the mid-20th century, there was an approximately decade-long interval during which methane concentrations exhibited little change, after which concentrations again began increasing (Rigby et al. 2008). Berner et al. (2003) have suggested that to understand these variations in the atmospheric methane concentrations, we must better establish the variability in the strengths of methane sources and sinks. Estimates of the oceanic contribution to the global methane budget range from 5 to $50 \mathrm{Tg}$ per year. This large uncertainty reflects the need for more detailed evaluation of marine areas with a potentially large contribution to the methane cycle, including areas with frequent upwelling events (Rehder et al. 2002, Kock et al. 2008) that stimulate high productivity and facilitate transfer of methane from the ocean to the atmosphere. Further, the northern Gulf of California (NGC) is known to be tectonically active and have high hydrothermal activity. When combined with the organic-rich sediments resulting from the high productivity and shallow water depths, these characteristics provide additional mechanisms for producing methane in the sediments, and facilitating its release to the water column and potentially the atmosphere (Campbell and Gieskes 1984, Canet et al. 2010).

It has been estimated that as much as $80 \%$ of the total global methane source of $600 \mathrm{Tg} \mathrm{CH}_{4} \mathrm{yr}^{-1}$ results from biological production by methanogens and the remaining $20 \%$ from geological sources (e.g., Kvenvolden and Rogers 2005). Methanogens are members of the strictly anaerobic Archaea, which compete with sulfate-reducing bacteria for reducing equivalents. Several potential sources may contribute methane to the marine water column, including biological production in the upper sediments and biological production within suspended particulates and the intestinal tracts of organisms such as fish and zooplankton (e.g., Traganza et al. 1979, Martens and Klump 1980, Kelley et al. 1990, de Angelis and Lee 1994, Tilbrook and Karl 1995, Kock et al. 2008). Abiogenic processes may be an important source of methane in tectonically active areas with higher than normal heat flow. In unsedimented areas, such as mid-ocean spreading centers, methane may be extracted from hot basalt by circulating seawater (e.g., Welhan 1988), or it may be formed by FischerTropsch reduction reactions associated with serpentinization (e.g., Proskurowski et al. 2008). In tectonically active areas with sediment cover, such as Guaymas Basin, thermal decomposition of sediment organic matter can be the dominant source of methane to the water column if gas transport pathways from the subsurface to the surface are available (e.g., Whelan and Lupton 1987). Physical processes such as dissolution of methane bubbles released by seepage and

\section{INTRODUCCIÓN}

El metano es un importante gas de efecto invernadero que aporta del 15\% (Amouroux et al. 2002) al 21\% (Houghton et al. 1990) del forzamiento radiativo total debido a los gases de invernadero de larga duración. Aunque la concentración de metano atmosférico ha ido en aumento desde mediados del siglo $\mathrm{XX}$, hubo un intervalo de aproximadamente una década durante el cual las concentraciones de metano exhibieron pocos cambios, después del cual empezaron a incrementar de nuevo (Rigby et al. 2008). Berner et al. (2003) sugirieron que para entender estas variaciones de las concentraciones de metano atmosférico, es necesario conocer mejor la variabilidad de las fuentes y sumideros de metano. Las estimaciones de la contribución oceánica al presupuesto global del metano varían de 5 a $50 \mathrm{Tg}$ por año. Esta gran incertidumbre refleja la necesidad de una evaluación más detallada de las zonas marinas con una aportación potencialmente grande al ciclo del metano, incluyendo las regiones donde frecuentemente se presentan eventos de surgencia (Rehder et al. 2002, Kock et al. 2008) que promueven una alta productividad y facilitan la transferencia de metano del océano a la atmósfera. Es bien conocido que la región norte del golfo de California (GC) es tectónicamente activa y presenta intensa actividad hidrotermal. Estas características, junto con los sedimentos ricos en materia orgánica resultantes de la alta productividad y profundidades de aguas someras, proporcionan mecanismos adicionales para producir metano en los sedimentos y facilitar su liberación en la columna de agua y potencialmente la atmósfera (Campbell y Gieskes 1984, Canet et al. 2010).

Se ha estimado que hasta el $80 \%$ de la emisión mundial de metano de $600 \mathrm{Tg} \mathrm{CH}_{4}$ año $^{-1}$ se debe a la producción biológica realizada por las arqueas metanógenas y el $20 \%$ restante a fuentes geológicas (e.g., Kvenvolden y Rogers 2005). Las bacterias metanógenas pertenecientes al dominio Archaea son estrictamente anaerobias y compiten con las bacterias reductoras de sulfato para los equivalentes reductores. Existen varias fuentes potenciales que pueden aportar metano a la columna de agua, incluyendo la producción biológica en los sedimentos superiores y la producción biológica dentro del material particulado suspendido y el tracto intestinal de organismos como peces y zooplancton (e.g., Traganza et al. 1979, Martens y Klump 1980, Kelley et al. 1990, de Angelis y Lee 1994, Tilbrook y Karl 1995, Kock et al. 2008). Los procesos abiogénicos pueden ser una fuente importante de metano en áreas tectónicamente activas con flujo de calor anormal. En áreas no sedimentarias, como los centros de dispersión oceánicos, el metano puede ser extraido del basalto caliente por el agua de mar circulante (e.g., Welhan 1988), o puede ser formado por las reacciones reductoras de FischerTropsch asociadas a la serpentinización (e.g., Proskurowski et al. 2008). En áreas tectónicamente activas con cobertura sedimentaria como la cuenca de Guaymas, la descomposición térmica de la materia orgánica del sedimento puede ser 
advection of water masses rich in methane may contribute to the methane concentration in a particular water column (Leifer et al. 2006). Biological consumption is an important sink of methane in the marine environment. Under oxic conditions, bacterial oxidation is the main sink (e.g., Ward and Kilpatrick 1993). Several modes of anaerobic oxidation of methane (AOM) have been documented (Joye 2012), including by consortia of anaerobic methanotrophic Archaea (ANME) and either sulfate-reducing bacteria (Orphan et al. 2001) or metal oxide-reducing bacteria (Beal et al. 2009), by an oxigenic bacterium that converts nitrite to $\mathrm{N}_{2}$ and $\mathrm{O}_{2}$ and uses the $\mathrm{O}_{2}$ to oxidize methane (Ettwig et al. 2010), and by an ANME that can couple AOM to disulfide disproportionation (Milucka et al. 2012).

Oceanographic areas with a high productivity or those with frequent upwelling events are often strong sources of methane to the atmosphere (Kock et al. 2008). The NGC (fig. 1) has been shown to exhibit high primary production (Zeitzschel 1969, Álvarez-Borrego and Lara-Lara 1991) in response to enhanced upward transport of nutrient-rich water. This enhanced productivity results in a high downward flux of particulate organic matter, decomposition of which may contribute to methane production in the sediments. The NGC begins just south of the large Midriff Islands (Tiburón, San Lorenzo, and San Esteban) and extends northward (fig. 1). The exchange of water between the NGC and the southern gulf is limited by the presence of sills of variable depth, of which the San Lorenzo (400 m depth) and San Esteban (600 $\mathrm{m}$ depth) sills (Padilla et al. 2006) are the most important.

\section{Geological setting and gas seepage in the Gulf of California}

The Gulf of California (GC) was formed by separation of the Baja California peninsula from the continent and subsequent drift of the peninsula to the northwest (Lonsdale 1989). An important determinant of GC structural geology is a tectonically-active system of long en echelon transform faults linked by pull-apart basins, which is part of the Pacific-North American plate boundary. These pull-apart basins were formed at short spreading centers, many of which are still active, including Guaymas Basin, which is about $100 \mathrm{~km}$ southeast of our study area. A combination of highly productive surface waters and input of riverine clastic sediments has led to a high rate of sedimentation and a $1.5-$ to $2-\mathrm{km}$-thick deposit of organic-rich sediments in Guaymas Basin (Merewether et al. 1985). This rapid deposition of sediments inhibits seafloor eruption, such as that observed at mid-ocean ridges, and intrusion of hot basaltic sills and dikes into the organic-rich sediments is the main igneous activity (Lonsdale and Becker 1985). The basaltic intrusions create a major geothermal anomaly (Lawver et al. 1975) and hydrothermal activity (Einsele et al. 1980), including generation of la fuente principal de metano a la columna de agua si existen rutas para transportar el gas de la subsuperficie a la superficie (e.g., Whelan y Lupton 1987). Procesos físicos como la disolución de burbujas de metano liberadas por la filtración y advección de masas de agua ricas en metano pueden contribuir a la concentración de metano en una columna de agua en particular (Leifer et al. 2006). El consumo biológico es un sumidero important de metano en el ambiente marino. En condiciones óxicas, la oxidación bacteriana es el principal sumidero (e.g., Ward y Kilpatrick 1993). Se han documentado varios modos de oxidación anaerobia de metano (OAM) (Joye 2012), incluyendo por consorcios de arqueas anaerobias metanotróficas (ANME) y ya sea bacterias reductoras de sulfato (Orphan et al. 2001) o bacterias reductoras de óxido (Beal et al. 2009), por una bacteria oxigénica que convierte el nitrito en $\mathrm{N}_{2}$ y $\mathrm{O}_{2}$ y utiliza el $\mathrm{O}_{2}$ para oxidar el metano (Ettwig et al. 2010), y por un ANME que puede acoplar OAM a la desproporcionación de disulfuro (Milucka et al. 2012).

Regiones oceanográficas de alta productividad o de surgencias frecuentemente actúan como fuentes de metano a la atmósfera (Kock et al. 2008). Se ha demostrado que la región norte del GC (fig. 1) presenta alta productividad primaria (Zeitzschel 1969, Álvarez-Borrego y Lara-Lara 1991) en respuesta a un mayor desplazamiento ascendente de agua rica en nutrientes. Este aumento de la productividad resulta en un alto flujo descendente de materia orgánica particulada, cuya descomposición puede contribuir a la producción de metano en el sedimento. La región norte del GC comienza justo al sur de las grandes islas (Tiburón, San Lorenzo y San Esteban) y se extiende hacia el norte (fig. 1). El intercambio de agua entre las regiones norte y sur del GC está limitado por la presencia de umbrales de profundidad variable, de los cuales San Lorenzo (400 m de profundidad) y San Esteban (600 $\mathrm{m}$ de profundidad) son los más importantes (Padilla et al. 2006).

\section{Situación geológica y filtración de gas en el golfo de California}

El GC se formó por la separación de la península de Baja California del continente y su subsecuente desplazamiento hacia el noroeste (Lonsdale 1989). Una importante determinante de la estructura geológica del GC es un sistema tectónicamente activo de largas fallas transformantes en echelon asociadas a cuencas de tracción (pull-apart basins), el cual se sitúa en el límite de las placas del Pacífico y Norteamericana. Estas cuencas de tracción se formaron en centros de dispersión cortos, muchos de los cuales aún son activos, incluyendo la cuenca de Guaymas que se ubica a unos $100 \mathrm{~km}$ al sureste de nuestra zona de estudio. Una combinación de aguas superficiales muy productivas y la entrada de sedimentos clásticos fluviales ha resultado en una tasa de sedimentación alta y un depósito de sedimentos ricos en materia orgánica de 1.5 a $2 \mathrm{~km}$ de espesor en la cuenca de Guaymas (Merewether 


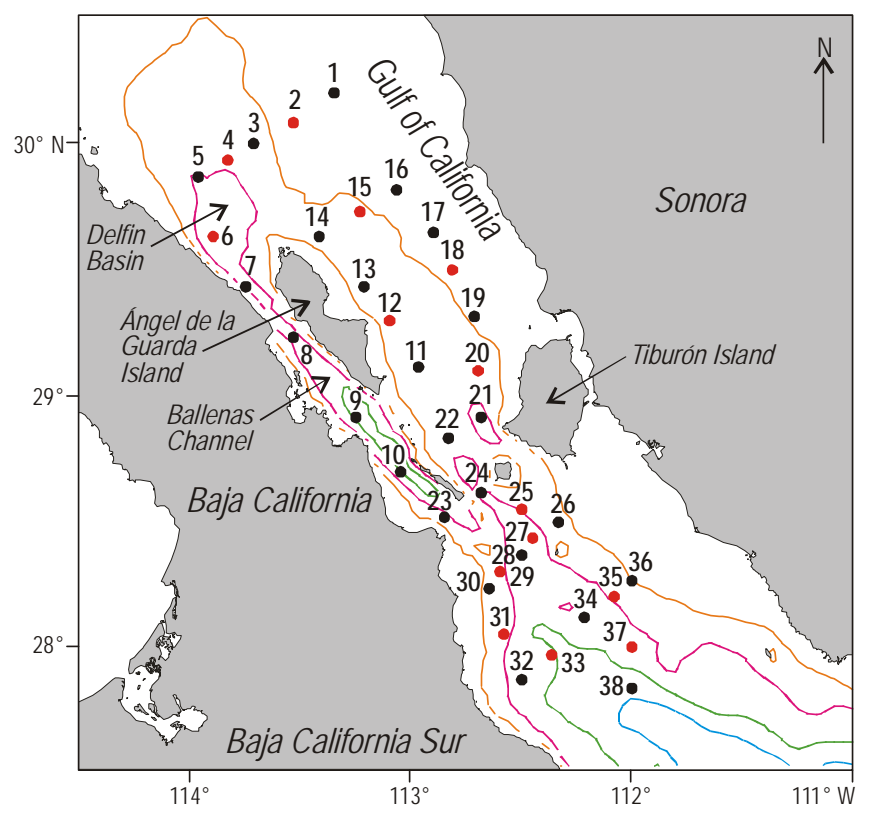

Figure 1. CTD stations where methane samples were collected in the northern Gulf of California are shown in black, whereas stations where only CTD was performed are shown in red. The $200 \mathrm{~m}$ (orange), $500 \mathrm{~m}$ (magenta), $1000 \mathrm{~m}$ (green), and $1500 \mathrm{~m}$ (blue) isobaths are shown.

Figura 1. Los círculos rojos indican las estaciones de muestreo donde sólo se realizaron lances de CTD y los círculos negros indican las estaciones CTD donde se recolectaron muestras de metano en la región norte del golfo de California. Se muestran las isóbatas de $200 \mathrm{~m}$ (naranja), $500 \mathrm{~m}$ (magenta), $1000 \mathrm{~m}$ (verde) y $1500 \mathrm{~m}$ (azul).

methane and other hydrocarbons by thermal decomposition of sedimentary organic matter (Whelan and Lupton 1987) in Guaymas Basin. The rate of thermogenic methane production in Guaymas Basin was found to be so great that it completely masked the abiogenic methane production that would be expected in this active spreading center based on observed ${ }^{3} \mathrm{He}$ anomalies (Whelan and Lupton 1987). As a consequence of the high methane production rate, many methane-rich thermal plumes have been documented in Guaymas Basin, some extending at least $900 \mathrm{~m}$ above the 1500-2000 m deep seafloor (Merewether et al. 1985). More recently, massive seafloor gas seepage from depths of 65 to $150 \mathrm{~m}$ was reported in the pull-apart Wagner and Consag basins (Canet et al. 2010), which are located about $100 \mathrm{~km}$ northwest of our study area. Known tectonically-active zones in our study area are the Ballenas Transform Fault (BTF) system within the Ballenas Channel (BC), and Delfín Basin. The BTF is part of the plate boundary and is thought to be the major locus of present transform movement in the Midriff Islands region (Bischoff and Henyey 1974), and the Delfin Basin contains an active spreading center (Lonsdale 1989, Persaud et al. 2003). et al. 1985). Esta rápida deposición de sedimentos inhibe la erupción del fondo marino, como se observa en las dorsales oceánicas, y la intrusión de umbrales y diques basálticos calientes en los sedimentos ricos en materia orgánica es la principal actividad ígnea (Lonsdale y Becker 1985). Las intrusiones basálticas producen una fuerte anomalía geotérmica (Lawver et al. 1975) y actividad hidrotérmica (Einsele et al. 1980), incluyendo la generación de metano y otros hidrocarburos por la descomposición de materia orgánica sedimentaria (Whelan y Lupton 1987) en la cuenca de Guaymas. Se ha documentado que la tasa de producción de metano termogénico en la cuenca de Guaymas es tan rápida que enmascara la producción de metano abiogénico que cabría esperar en este centro de dispersión activo con base en las anomalías de ${ }^{3} \mathrm{He}$ observadas (Whelan y Lupton 1987). Como consecuencia de la alta tasa de producción de metano, se han observado muchas plumas térmicas ricas en metano en la cuenca de Guaymas, algunas extendiéndose unos $900 \mathrm{~m}$ por arriba del lecho marino de 1500 a $2000 \mathrm{~m}$ de profundidad (Merewether et al. 1985). Más recientemente, se registró una masiva filtración de gas de profundidades de 65 a $150 \mathrm{~m}$ en las cuencas de tracción de Wagner y Consag (Canet et al. 2010), las cuales se localizan a unos $100 \mathrm{~km}$ al noroeste del área de estudio. Las zonas tectónicamente activas conocidas en el área de estudio son el sistema de falla transformante Ballenas (FTB) en el canal de Ballenas (CB) y la cuenca Delfín. El sistema de FTB se sitúa en el límite de placas y se considera el sitio principal del movimiento de placas tectónicas en la región de las grandes islas (Bischoff y Henyey 1974). La cuenca Delfín contiene un centro de dispersión activo (Lonsdale 1989, Persaud et al. 2003).

\section{Masas de agua}

Las masas de agua muestreadas en este estudio (fig. 2) han sido descritas previamente (ver, por ejemplo, Bray 1988, Delgadillo-Hinojosa et al. 2001). En la parte sur de la zona de estudio, la masa de agua más profunda fue la de Agua Intermedia del Pacífico (AIP), que se localizó entre 500 y $1000 \mathrm{~m}$ de profundidad. A profundidades intermedias $(100$ a $500 \mathrm{~m})$ se encontró Agua Subsuperficial Subtropical (ASS) directamente sobre AIP en toda la zona de estudio. Agua del Golfo de California (AGC) predominó a profundidades de 100 a $200 \mathrm{~m}$ en la zona de estudio, aunque en una estación se registró Agua Superficial Tropical (AST). Delgadillo-Hinojosa et al. (2001) han demostrado que ASS y probablemente AIP pueden contribuir agua rica en nutrientes al agua superficial de la región de las grandes islas del GC cuando se intensifica la mezcla vertical y, así, estimular la productividad primaria.

\section{Circulación en la región norte del golfo de California}

Es bien conocido que existe un intercambio tipo estuarino entre las regiones norte y sur del GC, en el cual agua rica en nutrientes, más fría y menos salina, que origina en el océano 


\section{Water masses}

The water masses sampled in this study (fig. 2) have been previously described (see for example Bray 1988, Delgadillo-Hinojosa et al. 2001). In the south, the deepest water mass was Pacific Intermediate Water (PIW), found at 500 to $1000 \mathrm{~m}$ depths. Subsurface Subtropical Water (SSW) directly overlies the PIW and occupies the intermediate depths $(100$ to $500 \mathrm{~m})$ throughout the study area. Gulf of California water (GCW) dominates the upper 100 to $200 \mathrm{~m}$ of the study area, although Tropical Surface Water (TSW) was observed at one station. Delgadillo-Hinojosa et al. (2001) have shown that SSW and probably PIW can contribute nutrient-rich water to the surface water in the Midriff Islands region of the $\mathrm{GC}$ via enhanced vertical mixing, and thus stimulate high primary productivity.

\section{Circulation in the northern Gulf of California}

It has long been recognized that the NGC has an estuarine-like exchange with the southern gulf, in which colder, less saline, nutrient-rich water originating in the Pacific Ocean (mainly SSW) inflows from the south at depth, and warmer, more saline, nutrient-depleted water (mainly GCW) outflows near the surface. This is believed to be a direct consequence of net heat gain and evaporation of the $\mathrm{NGC}$, which requires export of relatively warm and saline water and import of fresher and colder water to maintain heat and salt balances (Bray 1988, Lavín and Organista 1988).

Recently, direct current measurements at the San Esteban and San Lorenzo sills (see fig. 3) have estimated the net nearbottom inflow to be $0.18 \mathrm{~Sv}\left(1 \mathrm{~Sv}=1 \times 10^{6} \mathrm{~m}^{3} \mathrm{~s}^{-1}\right)$, equally divided between the two sills (López et al. 2006). The flow through the San Lorenzo sill (near station 30) descends to the deepest part of the $\mathrm{BC}$ in the form of an overflow, mixing vigorously as it descends from sill-depth $(\sim 400 \mathrm{~m})$ to the deepest part of the basin $(\sim 1600 \mathrm{~m})$. The flow through the San Esteban sill continues through the Tiburón Basin, eventually flowing over the Delfín sill (see fig. 3) and descending into Delfín Basin, the second deepest basin $(\sim 800 \mathrm{~m})$ in the NGC (López et al. 2008). Delfín Basin is connected to BC via the $\mathrm{BC}$ sill at $600 \mathrm{~m}$ depth (see fig. 3). Therefore, the two deepest basins in the NGC receive $0.18 \mathrm{~Sv}$ of water, which is continually discharged to their deepest parts. Both basins are closed below $400 \mathrm{~m}$ depth and connected by the BC sill. Therefore, water from the two-basin system cannot outflow below $200 \mathrm{~m}$ because the entering overflows extend 100 to $200 \mathrm{~m}$ above the bottom (400 $\mathrm{m}$ depth at the San Lorenzo and Delfín sills). A simple mass balance calculation taking into account the volume of both basins, their surface area, and the $0.18 \mathrm{~Sv}$ near-bottom inflow, results in a mean vertical velocity of approximately $5 \mathrm{~m}$ per day extending upwards to within at least $300 \mathrm{~m}$ of the surface in the BC and Delfín Basin (López et al. 2008). These vertical velocities are typical of strong upwelling areas, but in the NGC these are mean

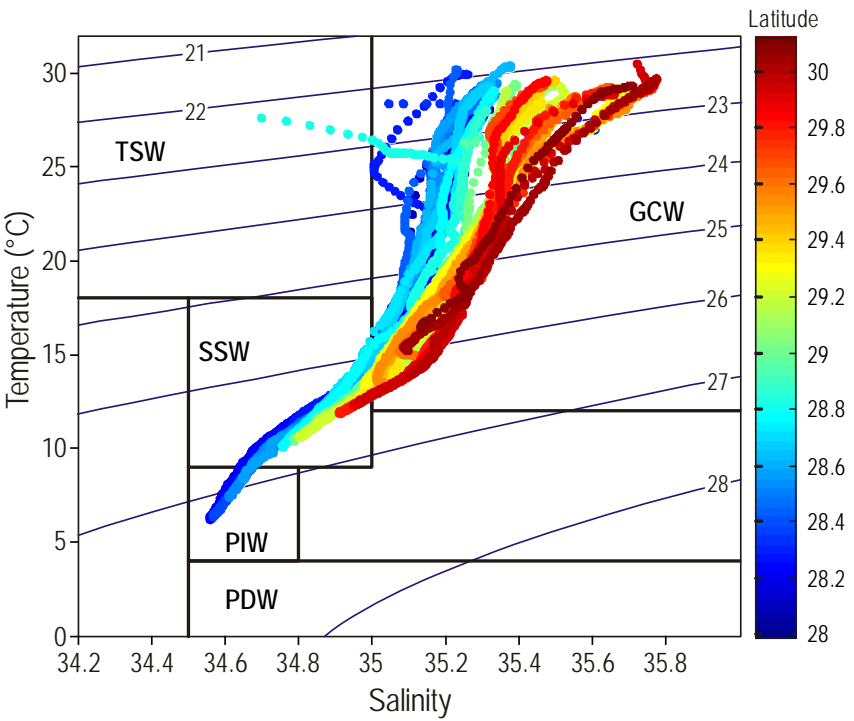

Figure 2. T-S diagram of all the CTD casts performed during the Umbrales III campaign in August 2003. Contours are for $\rho_{\theta^{-}}-1000$, where $\rho_{\theta}$ is potential density calculated at atmospheric pressure. TSW and PDW stand for Tropical Surface Water and Pacific Deep Water, respectively. The definitions for GCW, Gulf of California Water; SSW, Subsurface Subtropical Water; and PIW, Pacific Intermediate Water follow those of Torres-Orozco (1993) and Castro et al. (2006).

Figura 2. Diagrama T-S de todos los lances de CTD realizados durante la campaña de muestreo (Umbrales III) en agosto de 2003. Los contornos son para $\rho_{\theta}-1000$, donde $\rho_{\theta}$ es la densidad potencial a la presión atmósferica. Los acrónimos TSW y PDW significan Agua Tropical Superficial y Agua Profunda del Pacífico, respectivamente. Las definiciones de GCW, Agua del Golfo de California; SSW, Agua Subtropical Subsuperficial; y PIW, Agua Intermedia del Pacífico siguen las de Torres-Orozco (1993) y Castro et al. (2006).

Pacífico (principalmente ASS), fluye de sur a norte cerca del fondo, mientras que agua pobre en nutrientes, más caliente y más salina (principalmente AGC) fluye de norte a sur cerca de la superficie. Esto parece ser una consecuencia directa de la ganancia neta de calor y evaporación en la región norte del GC, lo cual requiere la exportación de agua relativamente caliente y salina, y la importación de agua menos salina y más fría para mantener los balances de sal y calor (Bray 1988, Lavín y Organista 1988).

Mediciones directas de corrientes en los umbrales de San Esteban y San Lorenzo (ver fig. 3) han mostrado que el flujo hacia el norte cerca del fondo es de $0.18 \mathrm{~Sv}$ (1 $\mathrm{Sv}=$ $\left.1 \times 10^{6} \mathrm{~m}^{3} \mathrm{~s}^{-1}\right)$, dividido equitativamente entre los dos umbrales (López et al. 2006). El flujo a través del umbral de San Lorenzo (cerca de la estación 30) desciende hasta la parte más profunda del $\mathrm{CB}$, causando un mezcla vigorosa conforme desciende de la profundidad del umbral $(\sim 400 \mathrm{~m})$ a la parte más profunda de la cuenca $(\sim 1600 \mathrm{~m})$. El flujo a través del umbral de San Esteban continúa por la cuenca Tiburón y eventualmente fluye sobre el umbral Delfín (ver fig. 3) y desciende en la cuenca Delfín, la segunda cuenca más 


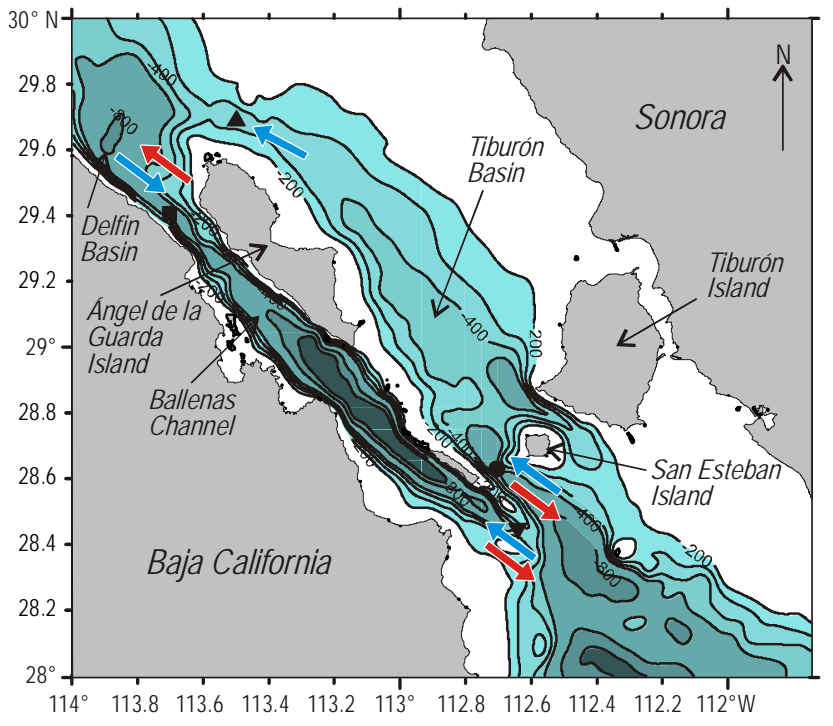

Figure 3. Map of the northern Gulf of California showing major basins and sills. Schematic representation of near-bottom (blue arrows) and near-surface (red arrows) flows. The black symbols represent the San Lorenzo $(\boldsymbol{\nabla})$, San Esteban $(\boldsymbol{O})$, Delfín $(\boldsymbol{\Delta})$, and Ballenas Channel (ם) sills. Isobaths are shown as solid lines.

Figura 3. Mapa de la región norte del golfo de California mostrando las cuencas y los umbrales principales. Representación esquemática de los flujos cerca del fondo (flechas azules) y cerca de la superficie (flechas rojas). Los símbolos negros representan los umbrales de San Lorenzo ( $)$, San Esteban (O), Delfín $(\boldsymbol{\Delta})$ y del canal de Ballenas (ם). Las isóbatas se indican como líneas continuas.

velocities, not just peak velocities during strong, wind-forced upwelling events. This rapid upward transport of nutrientrich water is responsible for the high biological productivity of the NGC, particularly BC that receives nutrient-rich, nearbottom SSW at both ends (López et al. 2006). A near-surface outflow of water must counterbalance the net deep inflow and associated upwelling in the $\mathrm{BC}$ and Delfín Basin. These near-surface outflows have been measured at the $\mathrm{BC}$ and San Lorenzo and San Esteban sills (fig. 3). At the BC sill the near-surface flow is located between 50 and $300 \mathrm{~m}$ depth and is directed out of the channel towards the northwest (López et al. 2006). A schematic representation of the near-bottom and near-surface circulation at the sills is shown in figure 3.

In this paper we report and evaluate dissolved methane concentrations in the Midriff Islands region of the NGC. We used the data to calculate sea-air methane fluxes to better understand the importance of marine areas characterized by high productivity and/or upwelling in the global methane cycle. We hypothesized that the NGC might be a strong methane source due to several characteristics: (1) high primary productivity and associated rapid biogeochemical cycling, (2) strong upward transport of methane-rich water from depth, and (3) the possible presence of thermogenic methane associated with hydrothermal and tectonic activity in relatively shallow (300 to $400 \mathrm{~m}$ depth) areas. We also profunda $(\sim 800 \mathrm{~m})$ en la región norte del GC (López et al. 2008). La cuenca Delfín se conecta con el CB mediante el umbral del canal a una profundidad de $600 \mathrm{~m}$ (ver fig. 3). Por lo tanto, las dos cuencas más profundas en la región norte del $\mathrm{GC}$ reciben $0.18 \mathrm{~Sv}$ de agua, que es constantemente transportada a sus partes más profundas. Ambas cuencas están cerradas por debajo de los $400 \mathrm{~m}$ de profundidad y conectadas por la cuenca del CB. Por ende, el agua en este sistema de dos cuencas no puede fluir hacia afuera por debajo de los $200 \mathrm{~m}$ porque los flujos entrantes se extienden 100 a $200 \mathrm{~m}$ por arriba del fondo ( $400 \mathrm{~m}$ de profundidad en los umbrales de San Lorenzo y Delfín). Un cálculo de balances de materia simple tomando en cuenta el volumen de ambas cuencas, su área superficial y el flujo cerca del fondo de $0.18 \mathrm{~Sv}$, arroja una velocidad vertical media de aproximadamente $5 \mathrm{~m}$ por día extendiéndose hacia arriba hasta por lo menos $300 \mathrm{~m}$ de la superficie del CB y la cuenca Delfín (López et al. 2008). Estas velocidades verticales son típicas de áreas de surgencia fuerte, pero en la región norte del GC son velocidades medias y no sólo velocidades máximas durante fuertes eventos de surgencia inducida por el viento. Este rápido transporte ascendente de agua rica en nutrientes es responsable de la alta productividad biológica en el norte del GC, especialmente en el CB que recibe ASS rica en nutrientes cerca del fondo en ambos extremos (López et al. 2006). Una salida de agua superficial debe contrarrestar la entrada neta de agua profunda y la surgencia asociada en el CB y la cuenca Delfín. Este flujo hacia afuera cerca de la superficie ha sido medido en el CB y en los umbrales de San Lorenzo y San Esteban (fig. 3). En el umbral de CB, el flujo cerca de la superficie se localiza entre 50 y $300 \mathrm{~m}$ de profundidad y es dirigida fuera del canal hacia el noroeste (López et al. 2006). En la figura 3 se presenta una representación esquemática de la circulación cerca del fondo y cerca de la superficie a través de los umbrales.

En el presente trabajo se analizan las concentraciones de metano disuelto registradas en la región de las grandes islas del GC. Se usaron los datos para calcular los flujos de metano entre el mar y la atmósfera para entender mejor la importancia de zonas marinas caracterizadas por una alta productividad y/o surgencias en el ciclo global del metano. Se planteó la hipótesis de que la región norte del GC podría ser una fuente de metano debido a varias características: (1) la alta productividad primaria y el rápido reciclado biogeoquímico asociado, (2) el fuerte transporte ascendente de agua rica en metano del fondo y (3) la posible presencia de metano termogénico asociado con la actividad hidrotérmica y tectónica en zonas relativamente someras (300 a $400 \mathrm{~m}$ de profundidad). También se analiza el uso potencial del metano como un trazador para diferenciar masas de agua y elucidar los flujos en el área de los umbrales.

\section{MATERIALES Y MÉTODOS}

Se obtuvieron muestras de agua en agosto de 2003, durante la tercera fase de una campaña realizada en la zona 
investigate the potential use of methane as a tracer in helping differentiate water masses and elucidate flows in the sills area.

\section{MATERIALS AND METHODS}

Water samples were collected in August 2003 during the third phase of the Umbrales campaign. The samples were collected at standard depths $(0,10,20,50,100,200,300$, $400,500 \mathrm{~m}$ and so on) at 24 stations using 5-L Go-Flo and Niskin bottles (fig. 1). Samples were then carefully transferred with minimal exposure to air to amber $250-\mathrm{mL}$ bottles, which were filled to the brim, poisoned with $\mathrm{HgCl}_{2}$, and tightly capped. Samples were kept cool and in the dark, and transported to the lab for analysis.

\section{Methane quantification}

The dissolved methane in each sample was determined using the phase equilibrium method between an aqueous sample and an inert gas phase (McAuliffe 1971, Capasso and Inguaggiato 1998) at standard conditions $\left(25^{\circ} \mathrm{C}, 1 \mathrm{~atm}\right)$. High purity helium was used as the inert gas. Quantification was carried out using a HP-6890 Series II gas chromatograph equipped with a flame ionization detector and a six-way valve with a 1-mL sample loop for sample introduction. We used a 15-m-long HP-PLOT/Molsieve column with a $0.53-\mathrm{mm}$ internal diameter and $50-\mu \mathrm{m}$ film thickness. The water vapor was removed by using a short piece of tubing (about $5 \mathrm{~cm}$ long) filled with active Drierite.

A seven-point calibration curve was derived from working standards, which were prepared by adding varying amounts of a $1000 \mathrm{ppb}$ methane standard (Scott Marrin, Inc.) with a gas-tight syringe to known volumes of high purity $\mathrm{He}$ in Kevlar gas sampling bags. All working standards were injected five times, and average peak areas (in $\mathrm{pA}^{*} \mathrm{~s}$ ) were calculated and used for the calibration. A typical calibration curve is shown in figure 4.

After the calibration was performed, a $50-\mathrm{mL}$ sample from each bottle was transferred to a gas-tight syringe. Each syringe was then placed in a water bath at $25^{\circ} \mathrm{C}$ for $15 \mathrm{~min}$; $20 \mathrm{~mL}$ of sample were removed from each syringe and replaced with $20 \mathrm{~mL}$ of high purity He. The syringes were then vigorously shaken for 15 min with a wrist-action shaker. Since methane is very insoluble in water (McAuliffe 1971, Wiesenburg and Guinasso 1979), it is rapidly transferred from the liquid phase to the gas phase, and shaking for more than 5 min results in transfer of $>90 \%$ of the methane to the headspace. The headspace methane concentration was then used to calculate the sample in situ methane concentration (Johnson et al. 1990). Based on the calibration curve, we estimated a limit of detection of $<0.1 \mathrm{nM}$. The uncertainty, measured from duplicate samples, was estimated to be $\sim 21 \%$.

The saturation rate of methane $(\mathrm{SR} \%)$ was then calculated by dividing the measured concentration $\left(C_{\text {measured }}\right)$ at the de umbrales (Umbrales III). Las muestras se recolectaron a profundidades estándar $(0,10,20,50,100,200,300,400$, $500 \mathrm{~m}$ y así sucesivamente) en 24 estaciones con botellas GoFlo y Niskin de 5 L. Las muestras fueron transferidas cuidadosamente, con mínima exposición al aire, a botellas de color ámbar de $250 \mathrm{~mL}$, las cuales fueron llenadas hasta el tope, envenenadas con $\mathrm{HgCl}_{2}$ y herméticamente cerradas. Las muestras se mantuvieron frescas y en la oscuridad, y se transportaron al laboratorio para su análisis.

\section{Cuantificación del metano}

Se determinó el metano disuelto en cada muestra mediante el método de equilibrio de fases entre una muestra acuosa y una fase de gas inerte (McAuliffe 1971, Capasso y Inguaggiato 1998) en condiciones estándar (25 $\left.{ }^{\circ} \mathrm{C}, 1 \mathrm{~atm}\right) . \mathrm{Se}$ usó helio de alta pureza como el gas inerte. La cuantificación se realizó usando un cromatógrafo de gases HP-6890 Serie II equipado con un detector de ionización de llama y una válvula de seis vías provista de un bucle de muestra de $1 \mathrm{~mL}$ para introducir la muestra. Se usó una columna HP-PLOT/ Molsieve de $15 \mathrm{~m}$ de largo con un diámetro interno de $0.53 \mathrm{~mm}$ y espesor de película de $50 \mu \mathrm{m}$. El vapor de agua se retiró con un trozo de tubo corto $(\sim 5 \mathrm{~cm}$ de largo) lleno de Drierite activo.

Se preparó una curva de calibración de siete puntos derivada de estándares de trabajo mediante la adición, con una jeringa hermética a los gases, de cantidades variables de un estándar de metano de 1000 ppb (Scott Marrin, Inc.) a volúmenes conocidos de He en bolsas para muestreo Kevlar. Todos los estándares fueron inyectados cinco veces, y los promedios de las áreas de los picos (en $\left.\mathrm{pA}^{*} \mathrm{~s}\right)$ fueron calculados y usados para la calibración. En la figura 4 se muestra una curva de calibración típica.

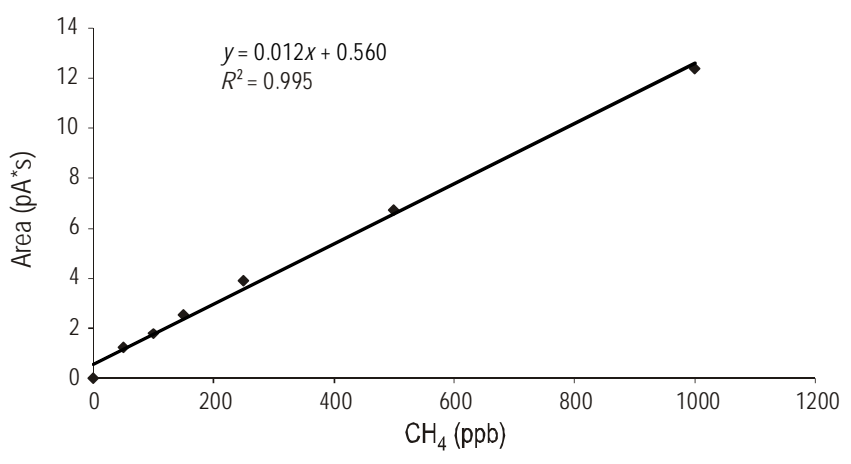

Figure 4. Methane $\left(\mathrm{CH}_{4}\right)$ calibration curve. Each data point represents the average of five independent measurements. Variations between determinations are smaller than the data symbols.

Figura 4. Curva de calibración del metano $\left(\mathrm{CH}_{4}\right)$. Cada punto representa el promedio de cinco mediciones independientes. Las variaciones entre las determinaciones son menores que los símbolos de datos. 
surface by the concentration that should exist if in equilibrium with the atmosphere $\left(C_{e q}\right)$, and multiplying by 100 :

$$
\mathrm{SR} \%=\left(C_{\text {measured }} / C_{\text {eq }}\right) \times 100
$$

This equilibrium concentration $\left(C_{e q}\right)$ was estimated using the polynomial derived by Wiesenburg and Guinasso (1979). Saturation values above 100 indicate a flux from the sea to the atmosphere.

\section{Methane flux calculations}

The flux of methane $\left(F\right.$ in $\mu$ mol m$\left.{ }^{-2} \mathrm{~d}^{-1}\right)$ from the ocean to the atmosphere was calculated by:

$$
F=k \times\left(C_{\text {measured }}-C_{e q}\right)
$$

where $k$ is the gas transfer coefficient $\left(\mathrm{m} \mathrm{d}^{-1}\right)$, which was calculated using a wind speed $(u)$ of $5.6 \mathrm{~m} \mathrm{~s}^{-1}$ for all methane flux calculations and using the Schmidt number $(S c)$ following the parameterization of Sweeney et al. (2007). The $S c$ is a function of the seawater temperature, gas diffusion coefficient, and water kinematic viscosity, and was calculated using the third-order polynomial expression derived by Wanninkhof (1992). The solubility of methane at equilibrium was calculated using the temperature and salinity dependence fit derived by Wiesenburg and Guinasso (1979). A wind speed of $5.6 \mathrm{~m} \mathrm{~s}^{-1}$ obtained from QuikSCAT was used for all methane flux calculations as mentioned above. A positive value of $F$ indicates net methane flux from the ocean to the atmosphere. We did not measure the atmospheric methane concentration during the cruise and assume that it was $1775 \mathrm{ppbv}$ (Sansone et al. 2004, Steele et al. 2002) for all calculations.

\section{RESUlts}

Temperature-salinity profiles obtained during the Umbrales III campaign in 2003 (fig. 2) clearly show the water masses that were sampled in the NGC. The profiles correspond to the stations shown in figure 1 .

The $\mathrm{BC}$ sill area (stations 7 and 8 ) appears to be a hotspot for methane production in the Midriff Islands region. The highest methane concentrations were found in near-surface samples in the BC-Delfín Basin area (figs. 5-8). In particular, station 7 at 50,20, and $0 \mathrm{~m}$ depths had methane concentrations of $49.1,48.3$, and $43.5 \mathrm{nM}$, respectively, which correspond to saturation values of $2090 \%, 2050 \%$, and $1850 \%$, respectively (fig. 5). Moreover, the whole $\mathrm{BC}$ water column is supersaturated with methane. The highest surface methane concentration was observed at station 7 , slightly north of the $\mathrm{BC}$ sill, which separates Delfin Basin from the BC (fig. 6). The horizontal methane fields suggest northwest to southeast transport along the $\mathrm{BC}$ and transport towards the northeast away from the $\mathrm{BC}$ sill at both the surface (fig. 6) and $50 \mathrm{~m}$
Después de realizar la calibración, se transfirió una muestra de $50 \mathrm{~mL}$ a una jeringa hermética a los gases. Cada jeringa fue colocada en un baño de agua a $25^{\circ} \mathrm{C}$ durante $15 \mathrm{~min}$. Se retiraron $20 \mathrm{~mL}$ de muestra de cada jeringa y se reemplazaron con $20 \mathrm{~mL}$ de He de alta pureza. Las jeringas fueron agitadas vigurosamente durante $15 \mathrm{~min}$ con un agitador de acción de muñeca. Ya que el metano es muy insoluble en agua (McAuliffe 1971, Wiesenburg y Guinasso 1979) se transfiere rápidamente de la fase líquida a la gaseosa y su agitación por más de 5 min produce una transferencia de $>90 \%$ del metano al espacio libre superior. La concentración de metano en el espacio libre se usó para calcular la concentración de metano in situ de la muestra (Johnson et al. 1990). Con base en la curva de calibración, se estimó un límite de detección de $<0.1 \mathrm{nM}$. La incertidubre, medida de muestras duplicadas, se estimó en $\sim 21 \%$.

La tasa de saturación de metano (TS\%) se calculó dividiendo la concentración medida ( $\left.C_{\text {medida }}\right)$ en la superficie entre la concentración que debería existir si estuviera en equilibrio con la atmósfera $\left(C_{e q}\right)$ y multiplicando por 100 :

$$
\mathrm{TS} \%=\left(C_{\text {medida }} / C_{e q}\right) \times 100
$$

Esta concentración de equilibrio $\left(C_{e q}\right)$ se estimó mediante el polinomio derivado por Wiesenburg y Guinasso (1979). Los valores de saturación por encima de 100 indican un flujo del mar a la atmósfera.

\section{Estimación del flujo de metano}

El flujo de metano ( $F$ en $\mu \mathrm{mol} \mathrm{m}^{-2} \mathrm{~d}^{-1}$ ) del océano a la atmósfera se calculó como sigue:

$$
F=k \times\left(C_{\text {medida }}-C_{e q}\right)
$$

donde $k$ es el coeficiente de transferencia del gas $\left(\mathrm{m} \mathrm{d}^{-1}\right)$, el cual se calculó usando la velocidad del viento de $5.6 \mathrm{~m} \mathrm{~s}^{-1}$ para todos los cáculos de flujo de metano y usando el número de Schmidt (Sc) siguiendo la parameterización de Sweeney et al. (2007). El Sc es una función de la temperatura del agua de mar, el coeficiente de difusión del gas y la viscosidad cinemática del agua, y se calculó con la expresión del polinomio de tercer orden derivada por Wanninkhof (1992). La solubilidad del metano en equilibrio se estimó mediante el ajuste de dependencia entre la temperatura y la salinidad derivado por Wiesenburg y Guinasso (1979). Se usó una velocidad del viento de $5.6 \mathrm{~m} \mathrm{~s}^{-1}$ obtenida de QuikSCAT para todos los cálculos de flujo de metano, tal como se menciona arriba. Un valor positivo de $F$ indica un flujo neto de metano del océano a la atmósfera. No se midió la concentración atmosférica del metano durante el crucero y se supuso que ésta fue de 1775 ppbv (Sansone et al. 2004, Steele et al. 2002) para todas las estimaciones. 


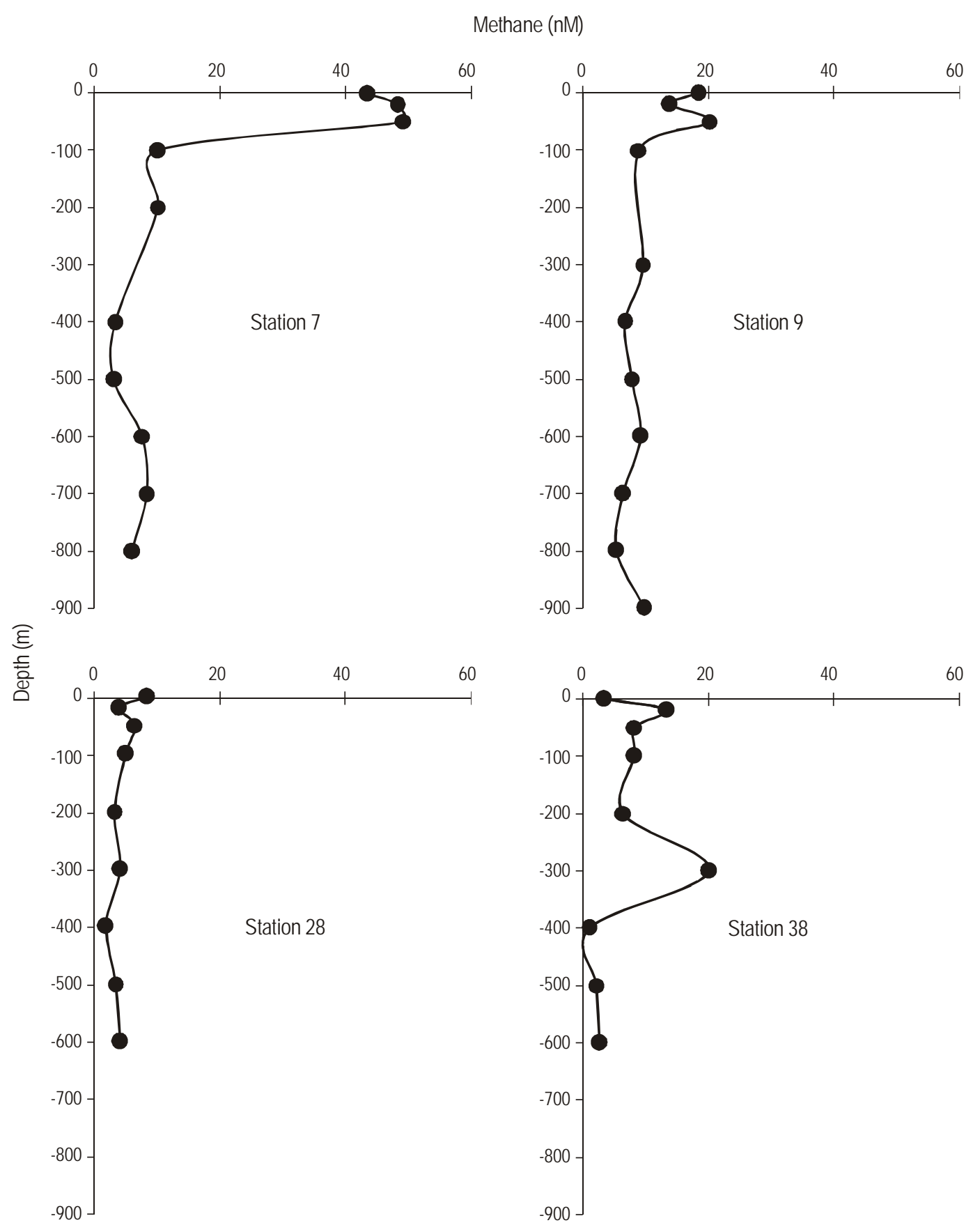

Figure 5. Vertical distributions of dissolved methane in the water column for stations marked. Subsurface maximums are visible at all stations. The maximum for station 38 at $300 \mathrm{~m}$ has been attributed to the presence of an oxygen minimum zone.

Figura 5. Distribuciones verticales del metano disuelto en la columna de agua de las estaciones indicadas. Los máximos subsuperficiales son visibles en todas las estaciones. El máximo para la estación 38 a 300 m ha sido atribuida a la presencia de una zona de mínimo de oxígeno.

depth (fig. 7). The unusual hydrography of the BC, in which near-surface outflows of upwelled water exit at both ends of the channel to counterbalance the inflows, probably explains these features of the horizontal methane fields. In addition, a deeper (300 m) methane maximum was detected at station 38 (fig. 5), which is located to the south of the sills and near the fringe of the Guaymas Basin (figs. 6, 9).

\section{RESUltados}

Los perfiles de temperatura y salinidad obtenidos durante la campaña Umbrales III en 2003 (fig. 2) muestran claramente las masas de agua muestreadas en la región norte del GC. Los perfiles corresponden a las estaciones que se muestran en la figura 1. 
A north to south methane section along stations 3, 14, 13, $11,22,24,28,34$, and 38 is shown in figure 9. GCW appears to be transporting methane southwards along the middle part of the NGC in the near-surface waters. The relatively high methane concentrations at stations 14,13 , and, to a lesser degree, 11, appear to be the result of advection from the $\mathrm{BC}$ sill area (station 7). The high concentrations coming from the BC sill area are transported in a fan-like pattern to the north, east, and south on the eastern side of Ángel de la Guarda Island. Since the transport is very near the surface $(\leq 100 \mathrm{~m})$, association with GCW is indicated. The 35 salinity isoline separates the GCW from the SSW (fig. 10). That isoline is found at depths $>200 \mathrm{~m}$ north of the sills. Advection of methane southwards (fig. 9) is mainly due to GCW. This water mass is found from the surface to around $200 \mathrm{~m}$ depth. The $300 \mathrm{~m}$ depth methane maximum at station 38 is just visible at the edge of figure 9, and a decreasing methane gradient towards the north and towards the surface away from this maximum is suggested.

We used the mean wind speed of $5.6 \mathrm{~m} \mathrm{~s}^{-1}$ obtained from Quickscat, and the approach described above to calculate the sea-air methane flux for all of our stations. All stations except 22 and 24 (which showed a slight undersaturation) were supersaturated with respect to the atmospheric equilibrium concentration. Our observed sea-air methane fluxes ranged

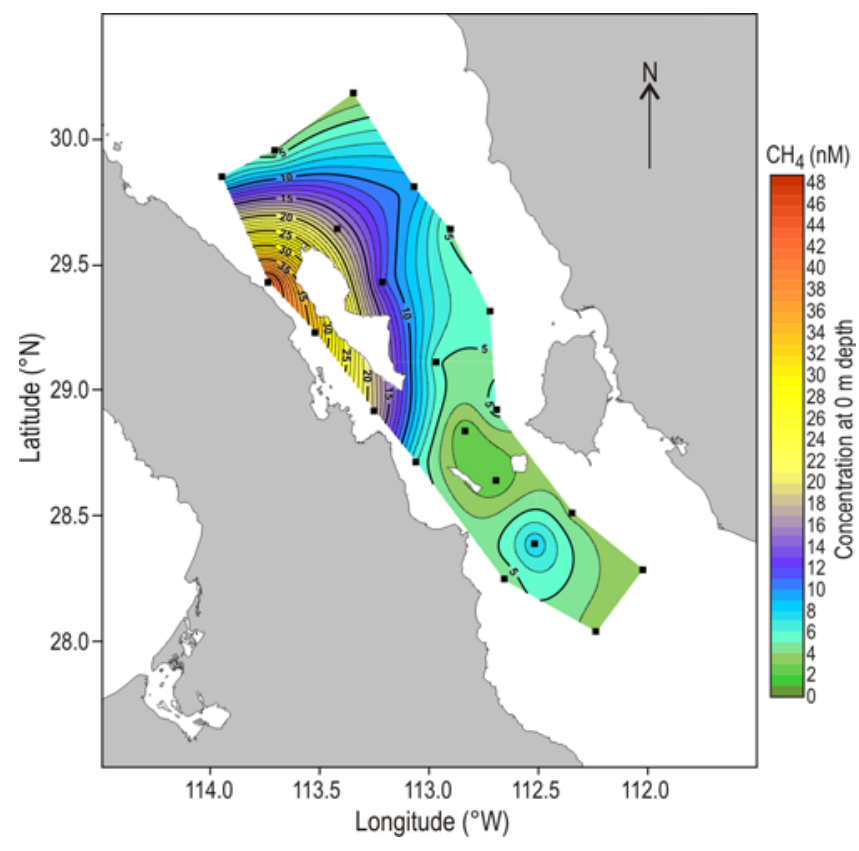

Figure 6. Surface methane $\left(\mathrm{CH}_{4}\right)$ concentration in the northern Gulf of California. Only the deep blue color represents zones with undersaturation of methane. Largest supersaturation was observed at the Ballenas Channel sites.

Figura 6. Concentración superficial de metano $\left(\mathrm{CH}_{4}\right)$ en la región norte del golfo de California. Sólo el color azul oscuro representa las zonas con subsaturación de metano. La mayor sobresaturación se observó en los sitios del canal de Ballenas.
La zona del umbral de CB (estaciones 7 y 8 ) parece ser un área crítica para la producción de metano en la región de las grandes islas. Las mayores concentraciones de metano se encontraron en las muestras recolectadas cerca de la superficie en la zona del CB y la cuenca Delfín (figs. 5-8). En particular, la estación 7 presentó concentraciones de 49.1, 48.3 y $43.5 \mathrm{nM}$ a 50,20 y $0 \mathrm{~m}$ de profundidad, respectivamente, que corresponden a valores de saturación de $2090 \%$, $2050 \%$ y $1850 \%$, respectivamente (fig. 5). Además, toda la columna de agua del CB se encuentra sobresaturada de metano. La mayor concentración de metano superficial se registró en la estación 7 , un poco al norte del umbral de $\mathrm{CB}$, que separa la cuenca Delfín del CB (fig. 6). Los campos horizontales de metano sugieren un transporte del noroeste al sureste a lo largo del CB y un transporte hacia el noreste del $\mathrm{CB}$ en tanto la superficie (fig. 6) como a $50 \mathrm{~m}$ de profundidad (fig. 7). La hidrografía inusual del $\mathrm{CB}$, donde los flujos salientes de agua aflorada cerca de la superficie en ambos extremos del canal contrarrestan los flujos entrantes, probablemente explica estas características de los campos horizontales de metano. También se detectó un máximo de metano más profundo $(300 \mathrm{~m}$ ) en la estación 38 (fig. 5), localizada al sur de los umbrales y cerca del borde de la cuenca de Guaymas (figs. 6, 9).

En la figura 9 se muestra una sección de metano de norte a sur a lo largo de las estaciones 3, 14, 13, 11, 22, 24, 28, 34 y 38. El AGC parece estar transportando metano en agua cerca de la superficie hacia el sur. Las concentraciones relativamente altas en las estaciones 14, 13 y, en menor grado,11, parecen ser resultado de la advección de la zona del umbral de CB (estación 7). Las concentraciones altas procedentes de

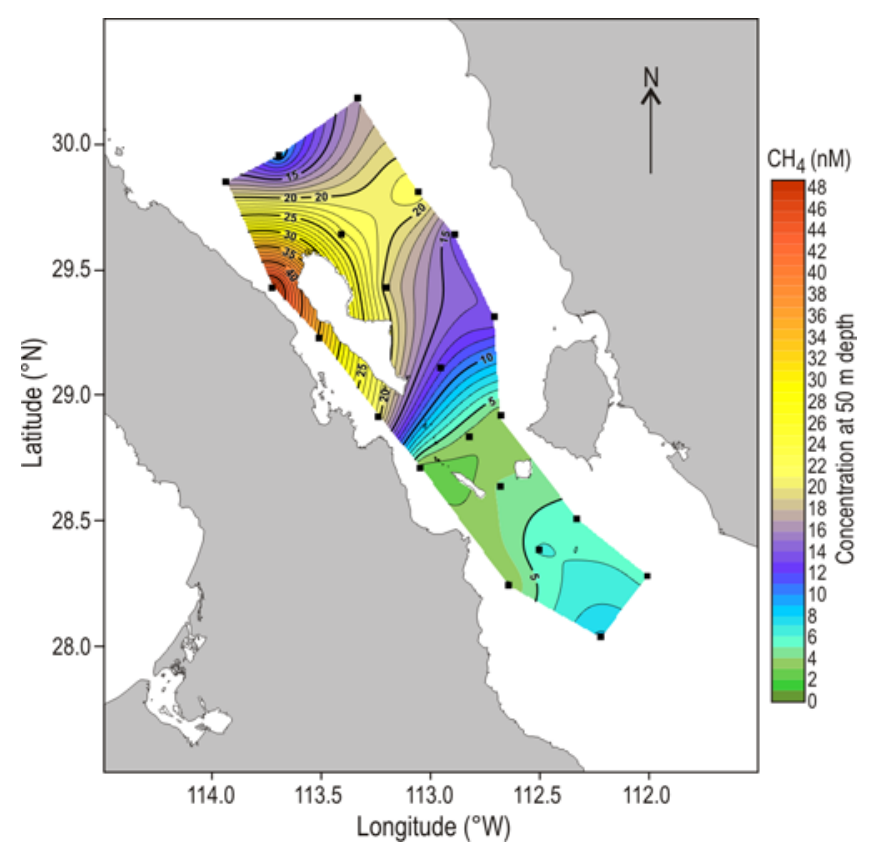

Figure 7. Methane $\left(\mathrm{CH}_{4}\right)$ concentration at $50 \mathrm{~m}$ depth.

Figura 7. Concentración de metano $\left(\mathrm{CH}_{4}\right)$ a $50 \mathrm{~m}$ de profundidad. 
from 3.4 to $103.4 \mu \mathrm{mol} \mathrm{m} \mathrm{m}^{-1}$ (table 1 ). The highest fluxes were observed for stations $7,8,9$, and 14 , with values of $103.4,79.5,39.3$, and $37.5 \mu \mathrm{mol} \mathrm{CH}_{4} \mathrm{~m}^{-2} \mathrm{~d}^{-1}$, respectively. Stations 7, 8, and 9 are all located in the $\mathrm{BC}$, where there is strong vertical mixing and high surface water methane concentrations (figs. 8, 11).

Subsurface maxima were located at or near the pycnocline usually around $50 \mathrm{~m}$ depth. In several instances, two relative methane maxima were observed in the vertical profiles (see for example fig. 5, stations 7 and 38). For stations 3 , 10, 21 (not shown), and 7, 28 and 38, the two methane maxima suggest more than one source of this gas. For stations 10 and 28, the methane maxima were observed at the surface and $50 \mathrm{~m}$ depth. Methane maxima were located at 0 and $200 \mathrm{~m}$ for station 21 and at 20 and $300 \mathrm{~m}$ for station 38.

\section{DISCUSSION AND CONCLUSIONS}

The measured average methane concentration for BC surface waters was $23.4 \mathrm{nM}$ (saturation about 1000\%), which results in an estimated methane flux of $74.1 \mu \mathrm{mol} \mathrm{m} \mathrm{m}^{-2} \mathrm{~d}^{-1}$. This is a very large value when compared to other values reported elsewhere (table 1). Assuming that $\mathrm{BC}$ has an area close to 270,000 ha, during summer the above flux would extrapolate to about $3.2 \mathrm{t} \mathrm{CH}_{4} \mathrm{~d}^{-1}$ from $\mathrm{BC}$ alone. An estimate for the whole sampling area using the average surface concentration for all surface samples yields about $4.9 \mathrm{t} \mathrm{d}^{-1}$, which emphasizes that $\mathrm{BC}$ is a hotspot of methane release in the NGC. We understand that spatial and temporal constraints limit the representativeness of our methane concentration data and the resultant estimated fluxes. This work was carried out on a ship of opportunity, and it was only possible to obtain one set of samples over a limited area.

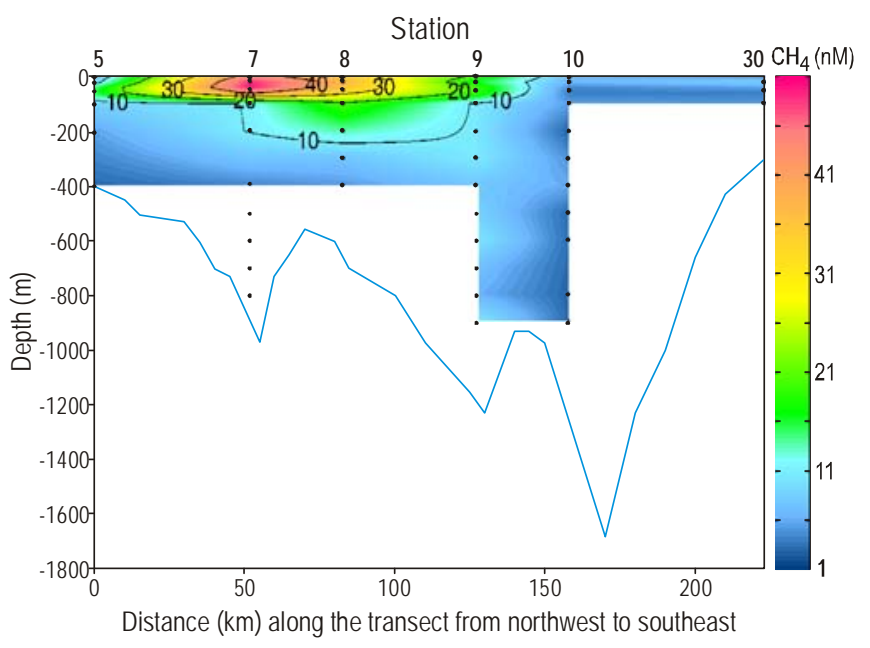

Figure 8. Methane $\left(\mathrm{CH}_{4}\right)$ section along the Ballenas Channel.

Figura 8. Sección de metano $\left(\mathrm{CH}_{4}\right)$ a lo largo del canal de Ballenas. la zona del $\mathrm{CB}$ son transportadas en forma de abanico hacia el norte, este y sur por el lado oriental de la isla Ángel de la Guarda. El transporte es muy cerca de la superficie $(\leq 100 \mathrm{~m})$, lo que indica una asociación con el AGC. La isolínea de salinidad de 35 separa el AGC del ASS (fig. 10). Tal isolínea se encuentra a profundidades $>200 \mathrm{~m}$ al norte de los umbrales. La advección de metano hacia el sur (fig. 9) se debe principalmente al AGC. Esta masa de agua se encuentra desde la superficie hasta unos $200 \mathrm{~m}$ de profundidad. La concentración máxima de metano a $300 \mathrm{~m}$ en la estación 38 es apenas visible en el margen de la figura 9, y se supone un gradiente decreciente hacia el norte y hacia la superficie de este máximo.

Se usaron la velocidad media del viento obtenida de Quickscat y el enfoque descrito anteriormente para calcular el flujo de metano del océano a la atmósfera para todas las estaciones. Todas las estaciones excepto 22 y 24 (que mostraron una ligera subsaturación) se encontraron sobresaturadas con respecto a la concentración en equilibrio con la atmósfera. Nuestros flujos de metano océano-atmósfera observados variaron de 3.4 a $103.4 \mu \mathrm{mol} \mathrm{m} \mathrm{m}^{-2} \mathrm{~d}^{-1}$ (tabla 1). Los mayores flujos de 103.4, 79.5, 39.3 y $37.5 \mu \mathrm{mol} \mathrm{CH}_{4} \mathrm{~m}^{-2}$ $\mathrm{d}^{-1}$ se observaron en las estaciones $7,8,9$ y 14 , respectivamente. Las estaciones 7,8 y 9 se ubican en el $\mathrm{CB}$, donde hay

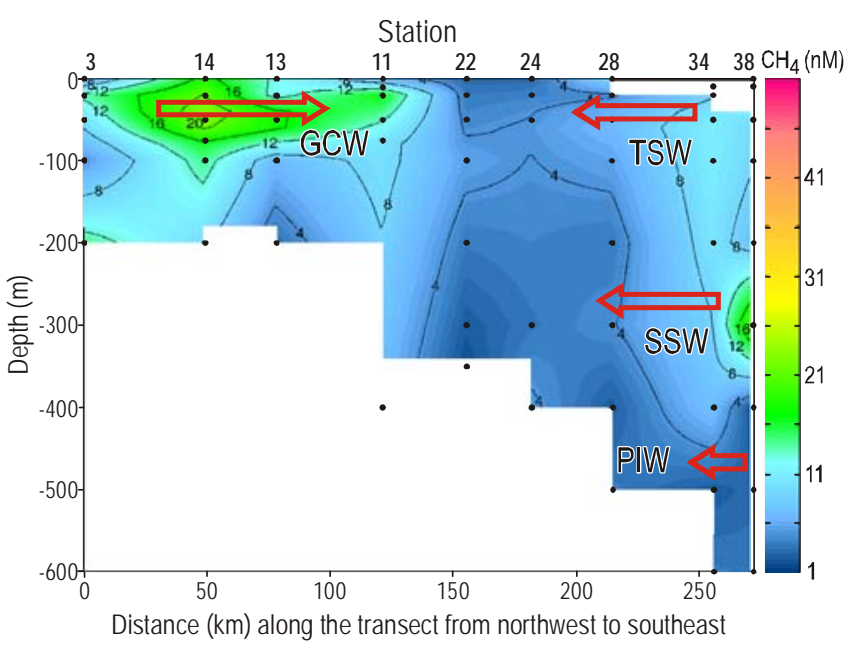

Figure 9. Methane $\left(\mathrm{CH}_{4}\right)$ section from north to south along stations $3,14,13,11,22,24,28,34$, and 38 (see fig. 1) in the northern Gulf of California. The deep blue color represents zones with methane undersaturation. Largest saturation was observed at $50 \mathrm{~m}$ depth. GCW, Gulf of California Water; TSW, Tropical Surface Water; SSW, Subsurface Subtropical Water; PIW, Pacific Intermediate Water.

Figura 9. Sección de metano $\left(\mathrm{CH}_{4}\right)$ de norte a sur a lo largo de las estaciones 3, 14, 13, 11, 22, 24, 28, 34 y 38 (ver fig. 1) en la región norte del golfo de California. El color azul oscuro representa las zonas con subsaturación de metano. La mayor saturación se observó a $50 \mathrm{~m}$ de profundidad. GCW, Agua del Golfo de California; TSW, Agua Superficial Tropical; SSW, Agua Subtropical Subsuperficial; PIW, Agua Intermedia del Pacífico. 
Processes that could be responsible for the methane concentrations that we observed in the NGC include biological production in the water column and sediments, thermal decomposition of sedimentary organic matter, and abiogenic production. With only methane concentration measurements available we cannot unambiguously distinguish among these possibilities. High rates of methane production coupled to intense biogeochemical cycling associated with high primary productivity stimulated by extensive inflow of nutrient-rich water over the sills at both ends of the BC (López et al. 2006) likely contribute to the generally elevated $\mathrm{BC}$ methane concentrations. The position of the maximum and the shape of the methane distribution gradients observed in figure 8 , and more clearly in figure 9 , suggest an in situ biological methane production in the water column, most likely in zooplankton guts (e.g., de Angelis and Lee 1994).

Although in situ methane production is probably an important contributor to the relatively modest levels of supersaturation observed throughout much of the NGC, a seafloor source, such as gas seepage from the sediments or methanerich hydrothermal fluids, is likely required to explain the very large saturation values detected in the BC. The station 9 profile (fig. 5), for example, shows a slight methane concentration increase with depth near the bottom, suggesting a possible sediment source. Evidence of hydrothermal activity in our study area includes an anomalously high sediment heat flow measurement in the $\mathrm{BC}$ within about $10 \mathrm{~km}$ of our station 8 (Lawver et al. 1975) and several volcanic knolls that have pierced the seafloor very near our stations 5 and 7

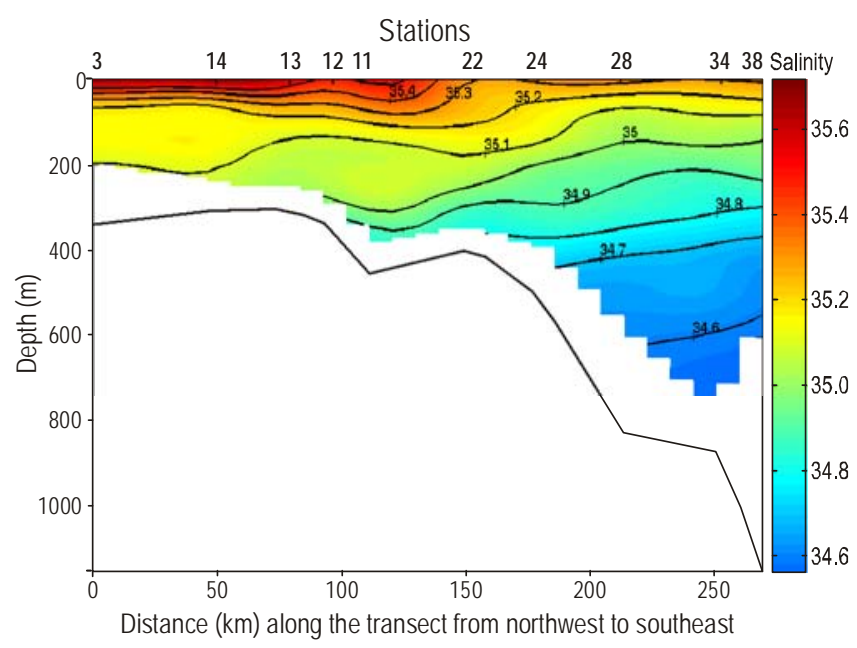

Figure 10. Salinity section along Tiburón Basin and San Esteban sill. Station numbers are marked above and north is at the left of the figure. The limit between Gulf of California Water and Subsurface Subtropical Water is marked by the 35 isohaline.

Figura 10. Sección de salinidad en la cuenca Tiburón y el umbral de San Esteban. Los números de las estaciones se indican en la parte superior y el norte se ubica a la izquierda de la figura. La isohalina de 35 indica el límite entre el Agua del Golfo de California y el Agua Subtropical Subsuperficial. fuerte mezcla vertical y altas concentraciones de metano en el agua superficial (figs. 8, 11).

Se localizaron máximos subsuperficiales en o cerca de la picnoclina generalmente alrededor de $\operatorname{los} 50 \mathrm{~m}$ de profundidad. En varios casos, se observaron dos máximos relativos de metano en los perfiles verticales (ver, por ejemplo, fig. 5, estaciones 7 y 38). En las estaciones 3, 10, 21 (no se muestran) y 7, 28 y 38 , los dos máximos de metano sugieren más de una fuente de este gas. En las estaciones 10 y 28, los máximos de metano se observaron en la superficie y a $50 \mathrm{~m}$ de profundidad. Los máximos de metano se localizaron a $0 \mathrm{y}$ $200 \mathrm{~m}$ en la estación 21 , y a 20 y $300 \mathrm{~m}$ en la estación 38 .

\section{DISCUSIÓN Y CONCLUSIONES}

La concentración promedio de metano medido para las aguas superficiales del CB fue de $23.4 \mathrm{nM}$ (saturación de alrededor de $1000 \%$ ), lo que resulta en un flujo de metano estimado de $74.1 \mu \mathrm{mol} \mathrm{m}{ }^{-2} \mathrm{~d}^{-1}$. Este valor es muy alto en comparación con los valores registrados por otros autores (tabla 1). Suponiendo que el CB tiene un área de cerca de 270,000 ha, durante el verano este flujo se extrapolaría a $3.2 \mathrm{t}$ $\mathrm{CH}_{4} \mathrm{~d}^{-1}$ de tan solo el CB. Una estimación más amplia de toda la zona usando la concentración promedio de todas las muestras superficiales arroja un valor de alrededor de $4.9 \mathrm{t}$ $\mathrm{d}^{-1}$, lo cual demuestra que el CB es un área crítica de liberación de metano en la parte norte del GC. Entendemos que restricciones espaciales y temporales limitan la representatividad de nuestros datos sobre la concentración de metano y los flujos resultantes estimados. Este trabajo se llevó a cabo en un crucero de oportunidad y sólo fue posible obtener un conjunto de muestras en un área limitada.

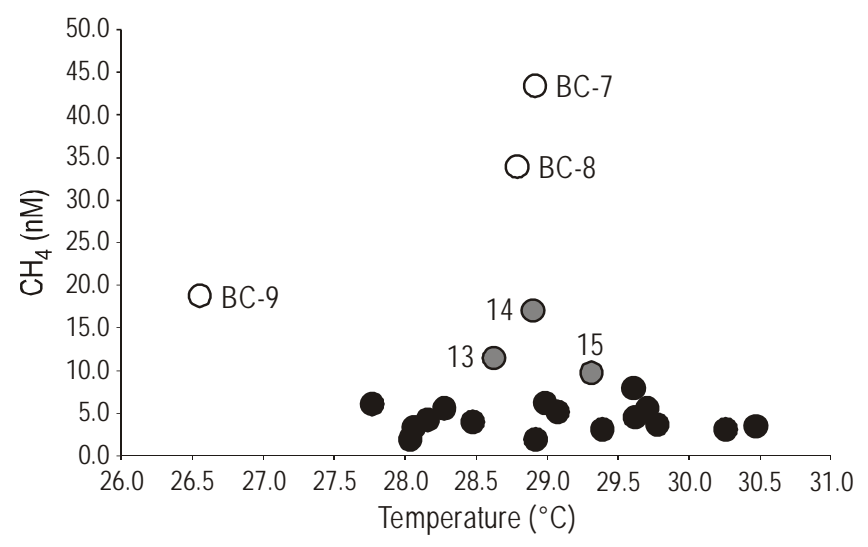

Figure 11. Methane $\left(\mathrm{CH}_{4}\right)$ concentration of surface samples versus water temperature. Ballenas Channel (BC) stations (numbers) showed the largest methane concentrations.

Figura 11. Concentración de metano $\left(\mathrm{CH}_{4}\right)$ en muestras superficiales versus temperatura del agua. Las mayores concentraciones de metano se registraron en las estaciones (números) del canal de Ballenas (BC). 
Table 1. Reported sea-air methane fluxes from different marine environments. Comparison to values obtained in this work is difficult due to differences in oeanographic conditions. Values are shown as intervals or as the mean \pm standard error.

Tabla 1. Flujos de metano del océano a la atmósfera registrados para diferentes ambientes marinos. Una comparación con los valores obtenidos en el presente trabajo es difícil debido a las diferentes condiciones oceanográficas. Los valores se muestran como intervalos o como la media \pm el error estándar.

\begin{tabular}{lcc}
\hline Geographic location & Reference & Flux $\left(\mu \mathrm{mol} \mathrm{CH}_{4} \mathrm{~m}^{-2} \mathrm{~d}^{-1}\right)$ \\
\hline V-4 Vortex & Tilbrook and Karl (1995) & $0.9-3.5$ \\
Mexican Pacific, all stations & Sansone et al. $(2004)$ & $0.5-5.9$ \\
Atlantic, overall transect & Kelley and Jeffrey (2002) & $0.38 \pm 0.32$ \\
Sargasso Sea & Holms et al. $(2000)$ & $1.6-4.4$ \\
Sea of Japan & Gamo et al. $(2012)$ & $2.64 \pm 1.92$ \\
East China Sea & Zhang et al. (2008) & $36.6 \pm 95.7$ \\
Yellow Sea & Zhang et al. $(2004)$ & $1.33 \pm 0.76$ \\
Pearl River Estuary & Zhou et al. $(2009)$ & $63.5 \pm 32.2$ \\
Northern South China Sea & Zhou et al. $(2009)$ & $15.6 \pm 8.0$ \\
Archaeon Lagoon, high-tide, France & Deborde et al. $(2010)$ & $4.8-40.8$ \\
Whole study area & This work & $21.1 \pm 5.0$ \\
Whole study area (range) & This work & $3.4-103.4 \pm 21.7$ \\
\hline
\end{tabular}

(Persaud et al. 2003). Faulting associated with the BTF system and intrusion of hot basalt into the upper sediment layers (e.g., volcanic knolls) would provide conduits for gas transport from the subsurface to the surface. Due to recent volcanic activity and/or strong bottom currents, much of the BTF has $<40$ m of sediment fill (Bischoff and Henyey 1974, Lonsdale 1989) compared to an estimated 1.5 to $2 \mathrm{~km}$ of sediment fill in Guaymas Basin. In areas of the BTF system with little or no sediment cover, we would expect generation of thermogenic methane to be less overwhelmingly important than it is in Guaymas Basin and abiogenic methane production to play a larger role. Assuming that the inferred methane seep is located in the BTF system and from an abiogenic source, we speculate that Fischer-Tropsch reduction reactions associated with serpentinization (e.g., Proskurowski et al. 2008) would be a more likely mechanism than extraction of methane from hot basalt by circulating sea water (Welhan 1988) because the serpentinization mechanism generally produces much higher methane concentrations (e.g., Charlou et al. 2010). If the inferred methane seep is located in Delfín Basin, then thermogenic methane production is more likely. Sedimentation rate in Delfín Basin is very high due to the high primary productivity of the area (Zeitzschel 1969, Álvarez-Borrego and Lara-Lara 1991) and its proximity to the Colorado River. The Delfín Basin sedimentation rate during the last 100 years ranged from 2.4 to $3.8 \mathrm{~cm} \mathrm{yr}^{-1}$ (Baba et al. 1991), which is about one order of magnitude higher than the Guaymas Basin sedimentation rate (Merewether et al. 1985). The high sedimentation rate would tend to protect the organic matter from biological decomposition, and where an intrusion of hot basalt occurs there would be the potential for
Los procesos que podrían ser responsables de las concentraciones de metano observadas en la región norte del GC incluyen la producción biológica en la columna de agua y sedimentos, la descomposición térmica de la materia orgánica sedimentaria y la producción abiogénica. No es posible distinguir claramente entre estas posibilidades con base en sólo las mediciones de la concentración de metano disponibles. Altas tasas de producción de metano junto con un reciclado biogeoquímico intensivo asociado con la alta productividad primaria estimulada por la entrada de agua rica en nutrientes a través de los umbrales en ambos extremos del CB (López et al. 2006) probablemente contribuyen a las generalmente elevadas concentraciones de metano en el CB. La posición del máximo y la forma de los gradientes de distribución de metano observadas en la figura 8, y con mayor claridad en la figura 9, sugieren una producción biológica de metano in situ en la columna de agua, probablemente en los intestinos de zooplancton (e.g., de Angelis y Lee 1994).

Si bien la producción de metano in situ probablemente sea un contribuidor importante a los niveles relativamente modestos de supersaturación observados en casi toda la región norte del GC, para explicar los elevados valores de saturación detectados en el CB se necesitaría una fuente del fondo marino, como las filtraciones de gas de los sedimentos o fluidos hidrotermales ricos en metano. El perfil de la estación 9 (fig. 5), por ejemplo, muestra un incremento ligero de metano hacia el fondo, lo que sugiere una posible fuente sedimentaria. La evidencia de actividad hidrotermal en la zona de estudio incluye una medida anómalamente alta de flujo de calor de sedimentos en el CB a unos $10 \mathrm{~km}$ de nuestra estación 8 (Lawver et al. 1975) y varios montículos volcánicos 
thermogenic methane production. An unknown variable is the sediment organic matter content, which, if too low due to high influx of Colorado River sediments, could limit thermogenic methane production. If no hydrothermal activity is present, then anoxic diagenesis of sedimentary organic matter can also form methane gas in the sediments, which may be released as bubbles to the water column. Release of methane bubbles from the sediments could be triggered (Canet et al. 2010) by the extensive faulting known to be present in the BC sill area (Persaud et al. 2003). Measurements of gas composition (i.e., ethane and propane) and methane stable isotope ratios could help to clarify the relative importance of the potential biogenic, thermogenic, and abiogenic sources and could also help constrain the importance of methane oxidation, but we were unable to obtain these measurements with our samples.

Methane advection from the south appears to be minor. A slight gradient from station 38 at $300 \mathrm{~m}$ depth (fig. 9), which is somewhat visible in figures 5 and 6 , was the only indication of methane advection from the south that we observed. Campbell and Gieskes (1984) estimated a water column methane anomaly of about $4 \mu \mathrm{M}$ from dilution of Guaymas Basin vent waters, and Merewether et al. (1985) observed that the plumes could extend to at least $900 \mathrm{~m}$ above the bottom, so it is conceivable that advection of methane-rich water from Guaymas Basin could account for the station 38 maximum of $\sim 20 \mathrm{nM}$. This small methane source, however, does not appear to reach across the sills into the northern stations. A longer lateral transport distance in oxygenated waters will necessarily translate into more complete in situ methane oxidation and relatively smaller fluxes to the atmosphere. The observed methane gradients are able to suggest water mass movement, as is evident from figures 5-8, and can be helpful in cases where several different water masses mix, as occurs in the NGC.

We observed unusually large methane concentrations and fluxes in the sills region of the NGC during a single sampling campaign. Additional data, such as the higher hydrocarbon (e.g., ethane and propane) concentrations and the isotopic signature of methane, with multiple sampling campaigns under a range of oceanographic conditions, more complete sampling over a wider area, and denser sampling of hotspots are needed to clarify the origin and cycling of methane and the importance of the area as an atmospheric methane source. Gas seepage from the sediments is likely to be highly localized and would be difficult to detect by fixed station water column sampling. Underway echo sounding (e.g., Canet et al. 2010) and/or deploying a towed or autonomous underwater vehicle with CTD and METS methane sensors (e.g., Merewether et al. 1985, Newman et al. 2008) would be a more efficient means of detecting methane and hydrothermal plumes over a wide area, such as the NGC, and would be helpful in pinpointing the locations of individual seeps, including the inferred seep near the BC sill. que han perforado el fondo marino muy cerca de nuestras estaciones 5 y 7 (Persaud et al. 2003). Fallas asociadas con el sistema de FTB y la intrusión de basalto caliente en las capas superiores de sedimento (e.g., montículos volcánicos) proporcionarían conductos para transportar gas de la subsuperficie a la superficie. Debido a la reciente actividad volcánica y/o las fuertes corrientes del fondo, gran parte del FTB tiene $<40$ m de relleno sedimentario (Bischoff y Henyey 1974, Lonsdale 1989) en comparación con 1.5 a $2 \mathrm{~km}$ de relleno sedimentario estimado para la cuenca de Guaymas. En áreas del sistema de FTB con poca o nula cobertura sedimentaria cabría esperar que la generación de metano termogénico sería mucho menos importante que en la cuenca de Guaymas y que la producción de metano abiogénico tendría un papel más importante. Suponiendo que la filtración de metano inferida se encuentra en el sistema de FTB y es de una fuente abiogénica, especulamos que las reacciones reductoras de Fischer-Tropsch asociadas con la serpentinización (e.g., Proskurowski et al. 2008) serían un mecanismo más probable que la extracción de metano de basalto caliente por el agua de mar circulante (Welhan 1988), ya que el mecanismo de serpentinización generalmente produce concentraciones de metano mucho mayores (e.g., Charlou et al. 2010). Si la filtración de metano se encuentra en la cuenca Delfín, entonces la producción de metano termogénico sería más probable. La tasa de sedimentación en la cuenca Delfín es muy alta debido a la elevada productividad primaria en la región (Zeitzschel 1969, Álvarez-Borrego y Lara-Lara 1991) y a su proximidad al río Colorado. Durante los pasados 100 años la tasa de sedimentación en la cuenca Delfín osciló entre 2.4 y $3.8 \mathrm{~cm}$ año ${ }^{-1}$ (Baba et al. 1991), lo cual es alrededor de un orden de magnitud mayor que la tasa de sedimentación en la cuenca de Guaymas (Merewether et al. 1985). Una tasa de sedimentación alta tendería a proteger la materia orgánica de descomposición biológica, y donde se produce una intrusión de basalto caliente habría el potencial para la producción de metano termogénico. Una variable desconocida es el contenido de materia orgánica en los sedimentos, ya que si es muy bajo debido a la entrada de sedimentos del río Colorado podría limitar la producción de metano termogénico. Si no existe actividad hidrotermal, entonces la diagénesis anóxica de la materia orgánica sedimentaria también puede formar gas metano en los sedimentos, el cual puede ser liberado en la columna de agua en la forma de burbujas. La liberación de burbujas de metano de los sedimentos puede ser activada (Canet et al. 2010) por las numerosas fallas que se encuentran en el umbral del CB (Persaud et al. 2003). Mediciones de la composición de gases (i.e., etano y propano) y las proporciones de isótopos estables de metano podrían ayudar a esclarecer la importancia relativa de las fuentes biogénicas, termogénicas y abiogénicas potenciales, así como la importancia de la oxidación de metano, pero no fue posible obtener estas mediciones con nuestras muestras.

Parece haber poca advección de metano del sur. La única indicación de advección del sur que se observó fue un ligero 


\section{ACKNOWLEDGMENTS}

Although this work was reviewed by the United States Environmental Protection Agency and approved for publication, it might not necessarily reflect Agency policy. Mention of trade names or commercial products does not constitute endorsement or recommendation for use. We would like to express our thanks to the National Council for Science and Technology (CONACYT, Mexico) for partially financing the project under contract \#G33464-T. We would also like to thank the crew of the oceanographic vessel Francisco de Ulloa for helping during the field work.

\section{REFERENCES}

Álvarez-Borrego S, Lara-Lara JR. 1991. The physical enviroment and primary productivity of the Gulf of California. In: Dauphin JP and Simoneit B (eds.), The Gulf and Peninsular Province of the Californias. Am. Assoc. Petr. Geol. 47: 555-567.

Amouroux D, Roberts G, Rapsomanikis S, Andreae MO. 2002. Biogenic gas $\left(\mathrm{CH}_{4}, \mathrm{~N}_{2} \mathrm{O}\right.$, DMS $)$ emission to the atmosphere from near-shore and shelf waters of the north-western Black Sea. Estuar. Coast. Shelf Sci. 54: 575-587. http://dx.doi.org/10.1006/ecss.2000.0666

Baba J, Peterson CD, Schrader HJ. 1991. Fine-grained terrigenous sediment supply and dispersal in the Gulf of California during the last century. In: Dauphin JP, Simoneit BRT (eds.), The Gulf and Peninsular Province of the Californias. Am. Assoc. Petr. Geol. Mem. 47: 589-602.

Beal EJ, House CH, Orphan VJ. 2009. Manganese- and irondependent marine methane oxidation. Science 325: 184-187. http://dx.doi.org/10.1126/science.1169984

Berner RA, Beerling DJ, Dudley R, Robinson JM, Wildman RA. 2003. Phanerozoic atmospheric oxygen. Annu. Rev. Earth Planet. Sci. 31: 105-134.

http://dx.doi.org/10.1146/annurev.earth.31.100901.141329

Bischoff JL, Henyey TL. 1974. Tectonic elements of the central part of the Gulf of California. Geol. Soc. Am. Bull. 85: 1893-1904. http://dx.doi.org/10.1130/00167606(1974) $85<1893$ :TEOTCP $>2.0$. CO;2

Bray NA. 1988. Water mass formation in the Gulf of California. J. Geophys. Res. 93(C8): 9223-9240. http://dx.doi.org/10.1029/JC093iC08p09223

Campbell AC, Gieskes JM. 1984. Water column anomalies associated with hydrothermal activity in the Guaymas Basin, Gulf of California. Earth Planet. Sci. Lett. 68: 57-72. http://dx.doi.org/10.1016/0012-821X(84)90140-7

Canet C, Prol-Ledesma RM, Dando PR, Vazquez-Figueroa V, Shumilin E, Birsota E, Sanchez A, Robinson CJ, Camprubi A, Tauler E. 2010. Discovery of massive seafloor gas seepage along the Wagner Fault, northern Gulf of California. Sediment. Geol. 228: 292-303.

Capasso G, Inguaggiato S. 1998. A simple method for the determination of dissolved gases in natural waters. An application to the thermal waters from Vulcano Island. Appl. Geochem. 13: 631-642. http://dx.doi.org/10.1016/S0883-2927(97)00109-1

Castro R, Durazo R, Mascarenhas A Jr, Collins CA, Trasvina A. 2006. Thermohaline variability and geostrophic circulation in the southern portion of the Gulf of California. Deep-Sea Res. (Part I) 53: 188-200.

http://dx.doi.org/10.1016/j.dsr.2005.09.010. gradiente en la estación 38 a $300 \mathrm{~m}$ de profundidad (fig. 9), el cual es algo visible en las figuras 5 y 6 . Campbell y Gieskes (1984) estimaron una anomalía de metano en la columna de agua de alrededor de $4 \mu \mathrm{M}$ por la dilución de aguas de ventilación de la cuenca de Guaymas, mientras que Merewether et al. (1985) observaron que las plumas podían extender hasta por lo menos $900 \mathrm{~m}$ por arriba del fondo; por lo tanto, es concebible que la advección de agua rica en metano de la cuenca de Guaymas podría explicar el máximo de $\sim 20 \mathrm{nM}$ en la estación 38. No obstante, esta pequeña fuente de metano no parece extenderse a través de los umbrales a las estaciones más al norte. Una mayor distancia de transporte lateral en aguas oxigenadas necesariamente se traducirá en una oxidación de metano in situ más completa y flujos relativamente menores a la atmósfera. Los gradientes de metano observados sugieren movimiento de las masas de agua, lo cual es evidente en las figuras 5 a 8 , y pueden ser útiles en casos donde se mezclan diferentes masas de agua, como es el caso de la región norte del GC.

Se observaron flujos y concentraciones de metano inusualmente altas en la zona de umbrales de la región norte del GC durante una sola campaña de muestreo. Para esclarecer el origen y ciclo del metano, y la importancia de la región como una fuente de metano atmósferico, se requieren datos adicionales tales como las concentraciones de otros hidrocarburos gaseosos (e.g., etano y propano) y la huella isotópica del metano, así como múltiples campañas de muestreo en una variedad de condiciones oceanográficas, y muestreos más completos en una zona más amplia y en zonas críticas. La filtración de gas de los sedimentos suele ser muy localizada y sería difícil de detectar mediante el muestreo de estaciones fijas en la columna de agua. Sondeos ultrasónicos (e.g., Canet et al. 2010) y/o el uso de vehículos submarinos autónomos o remolcados con sensores de metano CTD y METS (e.g., Merewether et al. 1985, Newman et al. 2008) serían medios más eficaces para detectar el metano y las plumas hidrotermales en una región amplia como el norte del GC, y serían útiles para ubicar las filtraciones individuales, incluyendo la filtración inferida en el umbral de CB.

\section{AgRAdecimientos}

Aunque este trabajo fue revisado por la Agencia de Protección Ambiental de los Estados Unidos y aprobado para su publicación, no necesariamente refleja la política de la agencia. La mención de marcas o productos comerciales no constituye aprobación o recomendación para su uso. Este trabajo fue parcialmente financiado por el Consejo Nacional de Ciencia y Tecnología (México) bajo el contrato \#G33464-T. Agradecemos a la tripulación del barco oceanográfico Francisco de Ulloa su apoyo durante el trabajo de campo.

Traducido al español por Christine Harris. 
Charlou JL, Donval JP, Konn C, Ondreas H, Fouquet Y, JeanBaptiste P, Fourre E. 2010. High production and fluxes of $\mathrm{H}_{2}$ and $\mathrm{CH}_{4}$ and evidence of abiotic hydrocarbon synthesis by serpentinization in ultramafic-hosted hydrithermal systems on the Mid-Atlantic Ridge. In: Rona PA et al. (eds.), Diversity of Hydrothermal Systems on Slow-spreading Ocean Ridges. AGU Monograph Series, Washington, pp. 265-296.

de Angelis MA, Lee C. 1994. Methane production during zooplankton grazing on marine phytoplankton. Limnol. Oceanogr. 39: 1298-1308. http://dx.doi.org/10.4319/lo.1994.39.6.1298

Deborde J, Anschutz P, Guérin F, Poirier D, Marty D, Boucher G, Thouzeau G, Canton M, Abril G. 2010. Methane sources, sinks and fluxes in a temperate tidal lagoon: the Arcachon Lagoon (SW France).

http://dx.doi.org/10.1016/j.ecss.2010.07.013

Delgadillo-Hinojosa F, Macías-Zamora JV, Segovia-Zavala JA, Torres-Valdés S. 2001. Cadmium enrichment in the Gulf of California. Mar. Chem. 75: 109-122. http://dx.doi.org/10.1016/S0304-4203(01)00028-7

Einsele G, Gieskes J, Curray J, Moore D, Aguayo E, Aubry MP, Fornari D, Guerrero J, Kastner M, Kelts K, Lyle M, Matoba M, Molina-Cruz A, Niemitz J, Rueda J, Saunders A, Schrader H, Simoneit B, Vacquier V. 1980. Intrusion of basaltic sills into highly porous sediments, and resulting hydrothermal activity. Nature 283: 441-445. http://dx.doi.org/10.1038/283441a0

Ettwig KF, Butler MK, Le Paslier D, Pelletier E, Mangenot S, Kuypers MM, Schreiber F, Dutilh BE, Zedelius J, de Beer D, Gloerich J, Wessels HTCT, van Alen T, Luesken F, Wu ML, van de Pas-Schoonen KT, Op den Camp HJM, Janssen-Megens EM, Francoijs KJ, Stunnenberg H, Weissenbach J, Jetten MSM, Strous M. 2010. Nitrite-driven anaerobic methane oxidation by oxygenic bacteria. Nature 464: 543-548. http://dx.doi.org/10.1038/nature08883

Gamo T, Tsunogai U, Hirota A, Nakayama N, Kang D, Kim K. 2012. First measurements of methane and its carbon isotope ratio in the Japan Sea (East Sea). Mar. Chem. 128-129: 92-99. http://dx.doi.org/10.1016/j.marchem.2011.10.006

Houghton JT, Jenkins GJ, Ephraums JJ. 1990. Climate change. The IPCC Assessment. Cambridge University, pp. 18-22.

Holmes ME, Sanson FJ, Rust TM, Pop BN. 2000. Methane production, consumption, and air-sea exchange in the open ocean: An evaluation based on carbon isotopic ratios. Global Biogeochem. Cycles 14: 1-10.

http://dx.doi.org/10.1029/1999GB001209

Johnson KM, Hughes JE, Donaghay PL, Sieburth JM. 1990. Bottle calibration static headspace method for the determination of methane dissolved in seawater. Anal. Chem. 62: 2408-2412. http://dx.doi.org/10.1021/ac00220a030

Joye SB. 2012. A piece of the methane puzzle. Nature 491: $538-539$ http://dx.doi.org/10.1038/nature11749

Kelley CA, Jeffrey WH. 2002. Dissolved methane concentration profiles and air-sea fluxes from $41^{\circ} \mathrm{S}$ to $27^{\circ} \mathrm{N}$. Global Biogeochem. Cycles 16: 13-11-13-16. http://dx.doi.org/10.1029/2001GB001809

Kelly CA, Marteens CS, Chanton JP. 1990. Variations in sedimentary carbon remineralization rates in the White Oak River estuary, North Carolina. Limnol. Oceanogr. 35: 372-383. http://dx.doi.org/10.4319/10.1990.35.2.0372

Kock A, Gebhardt S, Bange HW. 2008. Methane emissions from the upwelling area off Mauritania (NW Africa). Biogeosciences 5: $1119-1125$.

http://dx.doi.org/10.5194/bg-5-1119-2008
Kvenvolden KA, Rogers BW. 2005. Gaia's breath-global methane exhalations. Mar. Petrol. Geol. 22: 579-590. http://dx.doi.org/10.1016/j.marpetgeo.2004.08.004

Lavín MF, Organista S. 1988. Surface heat flux in the northern Gulf of California. J. Geophys. Res. 93: 14033-14038.

Lawver LA, Williams DL, Von Herzen RP. (1975). A major geothermal anomaly in the Gulf of California. Nature 257: 23-28. http://dx.doi.org/10.1038/257023aO

Leifer I, Luyendyk BP, Boles J, Clark JF. 2006. Natural marine seepage blowout: Contribution to atmospheric methane. Global Biogeochem. Cycles 20, GB3008. http://dx.doi.org/10.1029/2005GB002668

Lonsdale P. 1989. Geology and tectonic history of the Gulf of California. In: Winterer EL et al. (eds.), The Eastern Pacific Ocean and Hawaii. Geological Society of America, Boulder, Colorado. Geology of North America, VN, pp. 499-521.

Lonsdale P, Becker K. 1985. Hydrothermal plumes, hot springs, and conductivity heat flow in the southern trough of Guaymas Basin. Earth Planet. Sci. Lett. 73: 211-225. http://dx.doi.org/10.1016/0012-821X(85)90070-6

López M, Candela J, Argote ML. 2006. Why does the Ballenas Channel have the coldest SST in the Gulf of California? Geophys. Res. Lett.: 33, L11603. http://dx.doi.org/10.1029/2006GL025908.

López M, Candela J, García J. 2008. Two overflows in the northern Gulf of California. J. Geophys. Res. 113, C08023. http://dx.doi.org/10.1029/2007JC004575.

Martens CS, Klump JV. 1980. Biogeochemical cycling in an organic rich coastal marine basin. 1. Methane-sediment-water exchange process. Geochim. Cosmochim. Acta 44: 471-490. http://dx.doi.org/10.1016/0016-7037(80)90045-9

McAuliffe C. 1971. Gas chromatographic determination of solutes by multiple phase equilibrations. Chem. Technol. 1: 46-51.

Merewether R, Olsson MS, Lonsdale P. 1985. Acoustically detected hydrocarbon plumes rising from 2-km depths in Guaymas Basin, Gulf of California, J. Geophys. Res. 90(B4): 3075-3085. http://dx.doi.org/10.1029/JB090iB04p03075

Milucka J, Ferdelmann TG, Polerecky L. 2012. Zero-valent sulphur is a key intermediate in marine methane oxidation. Nature 491: 541-546. http://dx.doi.org/10.1038/nature11656

Newman KR, Cormier MH, Weissel JK, Driscoll NW, Kastner M, Solomon EA, Robertson G, Hill JC, Singh H, Camilli R, Eustice R. (2008). Active methane venting observed at giant pockmarks along the US mid-Atlantic shelf break. Earth Planet. Sci. Lett. 267: 341-352. http://dx.doi.org/10.1016/j.eps1.2007.11.053

Orphan VJ, House CH, Hinrichs K, McKeegan KD, DeLong EF. 2001. Methane-consuming Archaea revealed by directly coupled isotopic and filogenetic analysis. Science 293: 484-487. http://dx.doi.org/10.1126/science.1061338

Padilla F, López M, Ochoa J, Sheinbaum J. 2006. Hydrography and geostrophic currents in the northern Gulf of California during the 1997-1998 El Niño. Cont. Shelf Res. 26: 1154-1170. http://dx.doi.org/10.1016/j.csr.2006.03.005

Persaud P, Stock JM, Steckler MS, Martín-Barajas A, Diebold JB, González-Fernández A, Mountain GS. 2003. Active deformation and shallow structure of the Wagner, Consag, and Delfin basins, northern Gulf of California, Mexico. J. Geophys. Res. 108. http://dx.doi.org/10.1029/2002JB001937.

Proskurowski G, Lilley MD, Seewald JS, Früh-Green GL, Olson EJ, Lupton JE, Sylva SP, Kelley DS. 2008. Abiogenic hydrocarbon 
production at Lost City Hydrothermal Field. Science 319: 604607. htpp://dx.doi.org/10.1126/science.1151194

Rehder G, Collier RW, Heeschen K, Kosro PM, Barth J, Suess E. 2002. Enhanced marine $\mathrm{CH}_{4}$ emissions to the atmosphere off Oregon caused by coastal upwelling. Global Biogeochem. Cycles 16: 2-1-2-11. http://dx.doi.org/10.1029/2000GB001391

Rigby M, Prinn R, Fraser P, Simmonds P, Langenfelds R, Huang J, Cunnold D, Steele P, Krummel P, Weiss R, O'Doherty S, Salahem P, Wang H, Harth C, Mühle J, Porter L. 2008. Renewed growth of atmospheric methane. Geophys. Res. Lett. 35: L22805. http://dx.doi.org/10.1029/2008GL036037.

Sansone FJ, Graham AW, Berelson WM. 2004. Methane along the western Mexican margin. Limnol. Oceanogr. 49: 2242-2255. http://dx.doi.org/10.4319/1o.2004.49.6.2242

Steele LP, Krummel PB, Langenfelds RL. 2002. Atmospheric $\mathrm{CH}_{4}$ concentrations from sites in the CSIRO Atmospheric Research GASLAB air sampling network (October 2002 version). In: ORNL (ed.), Trends: A Compendium of Data on Global Change. Carbon Dioxide Information Analysis Center, US Department of Energy, Oak Ridge, TN.

Sweeney C, Gloor E, Jacobson AR, Key RM, McKinley G, Sarmiento JL, Wanninkhof R. 2007. Constraining global air-sea gas exchange for $\mathrm{CO}_{2}$ with recent bomb ${ }^{14} \mathrm{C}$ measurements. Global Biogeochem. Cycles 21: GB2015. http://dx.doi.org/10.1029/2006GB002784

Tilbrook BD, Karl DM. 1995. Methane sources, distributions and sinks from California coastal waters to the oligotrophic North Pacific gyre. Mar. Chem. 49: 51-64. http://dx.doi.org/10.1016/0304-4203(94)00058-L

Torres-Orozco E. 1993. Análisis volumétrico de las masas de agua en el Golfo de California. MSc thesis, Centro de Investigación Científica y de Educación Superior de Ensenada, México, 80 pp.
Traganza ED, Swinnerton JW, Cheek CH. 1979. Methane supersaturation and ATP-zooplankton blooms in near-surface waters of the Western Mediterranean and the subtropical North Atlantic Ocean. Deep-Sea Res. (Part A Oceanogr. Res. Pap.) 26: 1237-1245. http://dx.doi.org/10.1016/0198-0149(79)90066-9

Wanninkhof R. 1992. Relationship between wind speed and gas exchange over the ocean. J. Geophys. Res. 97 (C5): 7373-7382. http://dx.doi.org/10.1029/92JC00188

Ward BB, Kilpatrick KA. 1993. Methane oxidation associated with mid-depth methane maxima in the Southern California Bight. Cont. Shelf Res. 13: 1111-1122 http://dx.doi.org/10.1016/0278-4343(93)90044-X

Welhan JA. 1988. Origins of methane in hydrothermal systems. Chem. Geol. 71: 183-198. http://dx.doi.org/10.1016/0009-2541(88)90114-3

Whelan JA, Lupton JE. 1987. Light hydrocarbon gases in Guaymas Basin hydrothermal fluids: Thermogenic versus abiogenic origin. AAPG Bull. 71: 215-223.

Wiesenburg DA, Guinasso NL Jr. 1979. Equilibrium solubilities of methane, carbon monoxide and hydrogen in water and seawater. J. Chem. Eng. Data 24: 356-360.

Zeitzschel B. 1969. Primary productivity in the Gulf of California. Mar. Biol. 3: 201-207.

Zhang GL, Zhang J, Kang YB, Liu SM. 2004. Distributions and fluxes of methane in the East China Sea and the Yellow Sea in spring. J. Geophys. Res. 109, C07011. http://dx.doi.org/10.1029/2004JC002268.

Zhang GL, Zhang J, Ren JL, Li JB, Liu SM. 2008. Distributions and sea-to-air fluxes of methane and nitrous oxide in the North East China Sea in summer. Mar. Chem. 110: 42-55. http://dx.doi.org/10.1016/j.marchem.2008.02.005

Zhou H, Yin X, Yang Q, Wang H, Wu Z, Bao S. 2009. Distribution, source and flux of methane in the western Pearl River Estuary and northern South China Sea. Mar. Chem. 117: 21-31. http://dx.doi.org/10.1016/j.marchem.2009.07.011

Received September 2012, received in revised form January 2013, accepted February 2013. 